\title{
EL ART. 155 DE LA CONSTITUCIÓN ESPAÑOLA: EXAMEN DOCTRINAL Y COMPARADO
}

JOSÉ M. ${ }^{a}$ LAFUENTE BALLE 
SUMARIO

1. INTRODUCCIÓN: EL PROCÉS. EL ACUERDO DEL 27 DE OCTUBRE DE 2017 EN APLICACIÓN DEL ART. 155. UN PRECEPTO DESTACADAMENTE POLÍTICO, AMBIGUO E INCONCRETO; 2. EL ART. 155 Y LA TENSIÓN REGIONAL. MODELOS DE DERECHO COMPARADO; 3. LA INELUDIBLE REFERENCIA A LA COERCIÓN FEDERAL EN ALEMANIA. EL ART. 155 Y SU COMPARACIÓN CON EL 37 DE LA LEY FUNDAMENTAL DE BONN; 4. LA STGC DE 5 DE MARZO DE 1936; 5. LA COERCIÓN ESTATAL DEL ART. 155; 6. LOS TRÁMITES FORMALES PREVIOS A LA COERCIÓN ESTATAL DEL ART. 155; 7. LOS SUPUESTOS DE HECHO DEL ART. 155; 8. EL PROCEDIMIENTO DE LA COERCIÓN ESTATAL; 9. LAS MEDIDAS DEL ART. 155; 10. LA EXCEPCIONALIDAD POLÍTICA Y JURÍDICA DEL ART. 155. 


\title{
EL ART. 155 DE LA CONSTITUCIÓN ESPAÑOLA: EXAMEN DOCTRINAL Y COMPARADO
}

\author{
JOSÉ M. ${ }^{a}$. LAFUENTE BALLE ${ }^{1}$ \\ Profesor titular Derecho Constitucional \\ Universidad de Girona
}

\author{
1. INTRODUCCIÓN: EL PROCÉS. EL ACUERDO \\ DEL 27 DE OCTUBRE DE 2017 EN APLICACIÓN DEL ART. 155. \\ UN PRECEPTO DESTACADAMENTE POLÍTICO, \\ AMBIGUO E INCONCRETO
}

Hasta poco antes del Acuerdo del Senado, estaba persuadido de que jamás se aplicaría. Confiaba en la prudencia de los políticos para evitar un terreno tan sumamente impredecible. Durante los días del verano del 2017 en que elaboré la primera versión de este artículo, los principales diarios españoles dedicaban sus portadas a dos noticias principales: El conflicto Corea del Norte-U.S.A. y el procés independentista en Cataluña. No obstante la manifiesta lejanía geográfica entre ambos escenarios, sorprendía observar la coincidencia en un término: disuasión. En plena escalada verbal entre Kim Jong-un y Donald Trump, se sucedían las mutuas amenazas de agresión nuclear. Todos los grandes medios de comunicación del mundo coincidían en el efecto disuasorio del arsenal nuclear de uno y de otro. Ninguno de ellos parecía desear el conflicto bélico. También las noticias sobre Cataluña reportaban del art. 155 y su efecto disuasorio pero en un sentido perfectamente distinto. La Generalitat de Cataluña perseveraba en la desobediencia a la normativa constitucional; y el Gobierno central insistía en la imposibilidad del diálogo si solo se trataba de la convocatoria de un referendo de autodeterminación. En contra de lo que tantos creíamos, las posturas se alejaron y estalló lo que los medios de comunicación llamaron «el choque de trenes». La fecha del 3 de octubre se difundió un discurso del Rey Felipe VI llamando al orden constitucional y a la unidad del

${ }^{1}$ José M. ${ }^{a}$ Lafuente Balle. Profesor titular Derecho Constitucional. Universidad de Girona. Facultad de Derecho. Campus Montilivi.17003-GIRONA. Email: josep.lafuente@udg.edu 
Estado $^{2}$. No fue óbice para que la Generalitat declarase unilateralmente la República Catalana el 27 de octubre. Inmediatamente a continuación, el Gobierno central implementó el art. 155.

Nunca antes las opiniones pública y jurídica se habían interesado tanto por el art. 155 de la Constitución y los medios de coerción de los que dispone el Estado frente al incumplimiento por una Comunidad Autónoma de sus obligaciones constitucionales o cuando atente gravemente al interés general.

Como siempre sucede, una vez suscitado el litigio y la controversia constitucional, cada una de las partes se vale de la ambigüedad e incompletud que es distintiva de la Constitución y que determina que hayan de ser los Tribunales encargados de interpretar la Constitución quienes habrán de completar, en cada caso, el contorno de incerteza de la norma constitucional que aplican.

Dicho de otro modo, la inconcreción de la norma constitucional y su ambigüedad implican una mayor amplitud tanto de lo que los profs. Alchourron y Bulygin ${ }^{3}$ denominan el universo de casos relevante, como de lo que el prof. Moreso Mateos ${ }^{4}$ describe como sistemas jurídicos posibles; es decir, un mayor número de soluciones que sean a un tiempo eficaces para la resolución de los conflictos litigiosos subsumibles en la norma y coherentes con la Constitución. La polémica doctrinal sobre el mito de la unicidad de solución justa carece aún más de sentido por lo que a la aplicación del Derecho Constitucional se refiere. La inconcreción de las normas constitucionales favorece un número creciente de interpretaciones distintas y lógicas porque se dificulta determinar si el supuesto de hecho está o no comprendido en ella. La opción jurisprudencial a favor de una u otra interpretación implica una decisión necesariamente subjetiva. Es lo que el prof. Aguila ${ }^{5}$ efine como el «Arte de la interpretación de la oscuridad estructural de la Constitución». Todo ello es consecuencia de la característica fundamental de la norma constitucional que la distingue frente a cualquier otra norma jurídica, es decir su contenido político tal y como lo describió el prof. García Pelayo ${ }^{6}:$ «...Esta distribución que aquí sólo podemos enunciar pero no desarrollar, no coincide con la de Derecho público y privado o, dicho de otro modo, no todo el Derecho público tiene contenido ni significación políticos. Sí, en cambio, lo tienen el Derecho político y el Derecho constitucional, términos que en ocasiones se consideran sinónimos y en ocasiones interseccionados»

Suscitado el litigio e instada la controversia constitucional, la concepción sociológica de la norma constitucional se erige como la más eficaz (p. e. J. Ch. L. Simonde

\footnotetext{
2 Antonio Torres del Moral (2017): «Un reto y un discurso» en el diario madrileño «El Mundo», edición del 5 de octubre de 2017.

${ }^{3}$ Carlos E. Alchourrón y Eugenio Bulygin (1974): Introducción a la metodología de las ciencias jurídicas $y$ sociales. Ed. Astrea. Buenos Aires, pp. 146 a 148.

${ }^{4}$ José J. Moreso Mateos (1997): La indeterminación del Derecho y la interpretación de la Constitución. Centro de Estudios Constitucionales. Madrid.

5 Yann Aguila (1995): «Cinq questions sur l'interpretation constitutionnelle» en Revue Françoise de Droit Constitutionnel, n. ${ }^{\circ}$ 21. Presses Universitaires de France, pp. 16 y 17.

${ }^{6}$ Manuel García Pelayo (1982): «El status del Tribunal Constitucional» en Revista de Derecho Constitucional, n. ${ }^{\circ} 1$, Madrid, p. 24.
} 
de Sismondi, «Études sur les constitutions des peuples libres», 1836). Contrariamente a las concepciones racional e historicista, la tesis sociológica mantiene que la estructura política de un pueblo no es ni la consecuencia de una constitución aprobada ex novo ni el resultado de las costumbres seculares de un país, sino la sistematización jurídica de la estructura y realidad social del país y sus diversas circunstancias ambientales (p. e. Joseph de Maistre, «Considérations sur la France»1796, que se pregunta "¿Qué es una constitución? ¿No es cierto que no es otra cosa que la solución del problema siguiente? Dadas la población, las riquezas, las buenas y las malas cualidades de una determinada nación, encontrar las leyes que le convienen»).

Para la explicación del conflicto planteado por la Generalitat catalana resulta particularmente útil citar a Norberto $\mathrm{Bobbio}^{7}$ cuando describe la inextricable relación entre el Derecho y la realidad social en la que la norma jurídica rige porque el Derecho regula acciones políticas y las acciones políticas son acciones sociales: «toda acción política es una acción social en el doble sentido de acción interindividual y de acontecimiento grupal...» y «...la política tiene que ver con el derecho desde dos puntos de vista: en cuanto la acción política se lleva a efecto a través del derecho, y en cuanto el derecho delimita y disciplina la acción política...». La Constitución, en cuanto que norma fundamental del Ordenamiento jurídico, regula las actuaciones políticas y la fuerza de los gobernantes sobre los gobernados porque establece quien tiene el derecho de mandar y quienes la obligación de obedecer: "Quiere decir que es rey, en sentido más amplio, es soberano legítimo, y por tanto tiene la autoridad y no solamente el poder del más fuerte, la del que gobierna sustentado por un poder que le ha sido atribuido por una ley superior a él mismo»,

de manera que, a través de la Constitución se otorga un justo título a quien ha de detentar el Poder político y, por ende, autoridad para ejercerlo. En suma, N. Bobbio explica la relación entre el Poder y el Derecho, de forma que el Poder político se ejercita a través del Derecho y el Derecho es el límite del Poder político; o, desde otra perspectiva, el Poder político produce el Derecho para justificar y legitimar la fuerza que ejerce sobre los gobernados.

El art. 155 es un ejemplo paradigmático de norma constitucional ambigua e inconcreta ${ }^{8}$. El problema se suscita cuando, como en el presente caso, el contorno de incerteza de una norma es mayor que su núcleo de certeza. Cuando esto sucede, la aplicación de la norma deviene tortuosa, tanto por razones jurídicas como políticas. Ello no obstante, es lo cierto que el art. 155 prevé una acción política del Gobierno al que atribuye un poder político sujeto a un procedimiento. Estallado el conflicto, tendrá que ser el Tribunal Constitucional quien resuelva sobre el contorno de incerteza del precepto, evaluar si la acción del Gobierno se subsume en el universo de resoluciones posibles que no vulneren el contenido esencial de la norma y dictar una Sentencia.

7 Norberto Bobbio (1999): Teoria generale della política. Giulio Einaudi ed. Turín. Traducción al español Teoría general de la política. Ed. Trotta. Madrid 2003, pp. 237 a 275.

8 Rafael Entrena Cuesta (1985): «Artículo 155», en Luis M. Cazorla, Rafael Entrena, Ramón Entrena, F. Javier Gálvez, Emilio Recoder, Juan A. Santamaría, Fernando Santaolalla, José M. Serrano: «Comentarios a la Constitución». Ed. Civitas. Madrid, p. 2314. 
De la ya vasta Jurisprudencia del Tribunal Constitucional sobre el procés independentista, la Sentencia 259/2015 fue el precedente de todas las que le han sucedido. El recurso del Gobierno ex art. 161.2 de la Constitución tuvo por objeto la Declaración del Parlamento de Cataluña 1/XI de 9 de noviembre de 2015 que fue aprobada por la mayoría que conforman los diputados integrados en los grupos parlamentarios de Junts pel sí y la C.U.P. El texto no tiene parangón en el Derecho Comparado europeo. El Parlamento catalán afirma ser depositario de la soberanía del pueblo catalán; resuelve iniciar el proceso de creación de un Estado catalán independiente en forma de república y la apertura de un proceso constituyente; y reta con desobedecer las decisiones del Estado español en general y en particular las del Tribunal Constitucional al que niega legitimidad.

En los antecedentes de aquella sentencia consta que el Abogado del Estado alegó deslealtad constitucional a resultas de la vulneración de la Constitución, arts. 1, 2, 9.1 , 23, 164 y 168; el Estatuto de Autonomía, arts. 1, 2.4 y 4.1; además del sistema de distribución de competencias entre el Estado y la Generalitat. La tesis central del Gobierno es que la implementación de una soberanía del pueblo catalán y de su derecho a decidir exigiría la reforma de la Constitución por el trámite establecido en el art. 168. En su escrito de alegaciones, el Parlamento catalán aduce que la Resolución impugnada se apoya en los principios básicos de la democracia y el pluralismo político; responde al ejercicio de su función de impulso de la acción política y de gobierno ex art. 55.2 del Estatuto; y suplica que al carecer la Resolución de juridicidad, la impugnación interpuesta por el Abogado del Estado sea inadmitida a trámite.

Tras que el Tribunal Constitucional declarase reconocer la naturaleza jurídica de la Declaración 1/XI del Parlamento de Cataluña, entra en el fondo del asunto. La Sentencia estima la demanda del Gobierno, reitera la doctrina de la STC 42/2014 y enumera los fundamentos de su Fallo: la soberanía del pueblo español, la unidad nacional y el reconocimiento de las autonomías (art.2 C.E.); la supremacía de la Constitución (arts. 9.1 de la Constitución, 1 del Estatuto y 1 de la L.O.T.C.); el respeto a la democracia y el pluralismo político como valores superiores del ordenamiento jurídico (Preámbulo y arts. 1.1, 3, 148.1.17 y D.F. de la Constitución); la sujeción de la reforma constitucional a los procedimientos regulados en los arts. 167 y 168 :

«La Cámara autonómica no puede erigirse en fuente de legitimidad jurídica y política, hasta arrogarse la potestad de vulnerar el orden constitucional que sustenta su propia autoridad. Obrando de ese modo, el Parlamento de Cataluña socavaría su propio fundamento constitucional y estatutario (arts. 1 y 2.4 EAC, antes citados), al sustraerse de toda vinculación a la Constitución y al resto del ordenamiento jurídico, e infringiría las bases del Estado de Derecho y la norma que declara la sujeción de todos a la Constitución (arts. 1.1 y 9.1 CE). Este Tribunal dijo ya en la STC 103/2008 que el respeto a los procedimientos de reforma constitucional es inexcusable, de modo que "tratar de sortear, eludir o simplemente prescindir de esos procedimientos sería intentar una inaceptable vía de hecho (incompatible con el Estado social y democrático 
de Derecho que se proclama en el art. 1.1 CE) para reformar la Constitución al margen de ella o conseguir su ineficacia práctica" (FJ 4). Esto es lo recogido en realidad en la resolución 1/XI, cuya apariencia de juridicidad — por provenir de un poder sin duda legítimo en origen- debe ser cancelada mediante la declaración de inconstitucionalidad que aquí se decide.»

También la última Sentencia del Tribunal Constitucional sobre el procés secesionista en Cataluña insiste en estos argumentos. La STC 114/2017 estima el recurso del Gobierno y declara inconstitucional la Ley del Parlamento de Cataluña 19/2017 del referéndum de autodeterminación. Esta Ley que dice ser suprema a cualquier otra, regula un referéndum para la eventual independencia de la Comunidad Autónoma de Cataluña (arts. 1, 4 y conexos) sobre la base de una pretendida soberanía del pueblo catalán (art. 2) de la que sería representante el propio Parlamento de la Comunidad Autónoma (art. 3.1). Los fundamentos de la Sentencia enumeran razones procedimentales por manifiesta vulneración de los arts. 81.3 y 82 del Reglamento del Parlament: En el procedimiento de apenas 11 horas se ignoraron los derechos de los diputados de la oposición a quienes se les denegó la documentación objeto de debate, se obvió el dictamen del Consell de Garanties Estatutaries de 6 de septiembre de $2017^{9}$ y no se admitieron enmiendas de totalidad. No menos rotundas son las razones materiales por manifiestas vulneraciones del texto constitucional: subvierte el sistema de fuentes porque ignora la supremacía de la Constitución (art. 9.1); vulnera el principio de soberanía nacional (art. 2.1); es inconciliable con la unidad de la Nación española que solo es modificable a través del procedimiento de reforma del art. 168; infringe los principios estructurales del ordenamiento (STC 128/2016): «La Ley 19/2017 es, con toda evidencia, inconstitucional y lo es en su conjunto al contrariar, de modo explícito, principios esenciales de nuestro ordenamiento constitucional: la soberanía nacional, residenciada en el pueblo español, la unidad misma de la Nación constituida en Estado social y democrático de derecho, y la propia supremacía de la Constitución, a la que están sujetos todos los poderes públicos y también, por tanto, el Parlamento de Cataluña (arts. 1.2, 2, 1.1 y $9.1 \mathrm{CE}$ )».

No obstante las resoluciones del Tribunal Constitucional, el Gobierno de Cataluña ha insistido en sus postulados sobre el derecho a decidir del pueblo catalán hasta proclamar la creación de un nueva República catalana. La reacción del Estado ha sido la implementación del art. 155 («1. - Si una Comunidad Autónoma no cumpliere las obligaciones que la Constitución u otras leyes le impongan, o actuare de forma que atente gravemente al interés general de España, el Gobierno, previo requerimiento al Presidente de la Comunidad Autónoma y, en el caso de no ser atendido, con la aprobación por mayoría absoluta del Senado, podrá adoptar las medidas necesarias para obligar a aquélla al cumplimiento forzoso de dichas obligaciones o para la protección del mencionado interés general. 2.- Para la ejecución de las medidas previstas en el apartado anterior, el Gobierno podrá dar instrucciones a todas las autoridades de las Comunidades Autónomas»).

9 https://www.cge.cat/contingut.php?id_pagina $=18$ 
Llegados a este capítulo, se trata de discernir sobre el alcance de la atribución constitucional al Gobierno y la constitucionalidad de las medidas adoptadas en el Acuerdo de 27 de octubre de 2017.

En la «cuestión catalana» se enfrentan dos concepciones antagónicas. De una parte, quienes reivindican los principios de legalidad y juridicidad propios del constitucionalismo desde sus inicios; y de otra, las teorías de la desobediencia.

El principio de legalidad es el gran avance de la Revolución francesa. Significó el fin del absolutismo. A partir de entonces la ley ya no solo regía para los ciudadanos sino también para los poderes políticos. El Preámbulo de la Déclaration des droits de l'bomme et du citoyen debido a Jean-Joseph Mounier, al Abad Sièyes y el Conde de Mirabeau ha devenido una pieza clásica del Derecho Constitucional. En su Teoría general del Derecho Administrativo, Adolf Merk $1^{10}$ teorizó sobre el principio de legalidad y contradijo la teoría proveniente de la antigua Monarquía constitucional según la cual era posible una Administración que actuase al margen de la ley positiva. Antes al contrario, no existe un poder de la Administración para actuar al margen de las leyes, de aquí su sujeción a los tribunales. Más concreto, Ignacio de Otto ${ }^{11}$ estudia el principio de legalidad como principio de juridicidad y escribe: «El principio de juridicidad no explica otra cosa que la idea de una limitación jurídica del poder político, entendido el término limitación en un sentido amplio. Se trata de una concreción del principio del Estado de Derecho, que exige la limitación jurídica del poder del Estado, exigencia llevada a sus últimas consecuencias con la sujeción del propio legislador a la Constitución. El principio de juridicidad impone, por tanto, la existencia de normas jurídicas que vinculan a la Administración cuando actúa y que de este modo la someten a derecho»

Las teorías de la desobediencia y la resistencia al Derecho han sido más objeto de la Iusfilosofía ${ }^{12}$. Sin embargo, algún constitucionalista se ha hecho eco de estas teorías y particularmente Roberto Gargarella. Defiende este autor el derecho de grupos alienados a la desobediencia civil frente al Derecho como un todo, incluso en las democracias consolidadas: «No deben caber dudas, en la actualidad, acerca de la existencia de importantes segmentos de la sociedad que tienen serias dificultades para satisfacer sus necesidades más básicas, para hacer conocer sus puntos de vista; para demandar de modo exitoso por la introducción de cambios en el derecho, o para reprochar las acciones y omisiones de sus representantes» ${ }^{13}$. «En tales situaciones, cuando el Estado comienza a utilizar su fuerza en favor del mantenimiento de una situación institucional fundamentalmente injusta, es que pueden apare-

10 Adolf Merkel (1927): Allgemeines Verwaltungsrecht. Julius Springer. Wien-Berlin. Traducción al español: Teoría general del Derecho Administrativo. Ed. Comares, Granada 2016.

11 Ignacio de Otto Pardo (1987): Derecho Constitucional. Sistema de fuentes. Ed. Ariel. Barcelona, p. 157. V. también, Francisco Rubio Llorente (1993): «El principio de legalidad» en Revista Española de Derecho constituciona,l n. ${ }^{\circ}$ 39. Madrid, pp. 9 a 42.

12 Jorge F. Malem Seña (1990): Concepto y justificación de la desobediencia. Ed. Ariel. Barcelona.

13 Roberto Gargarella (2007): «El derecho de resistencia en situaciones de carencia extrema», en Astrolabio, n. ${ }^{\circ}$ 4. Universitat de Barcelona, pp. 1 a 29. 
cer o resultar justificadas ciertas acciones de resistencia: el grado en que ello sea así dependerá, por supuesto del mayor o menor nivel de alienación legal existente. ${ }^{14}$

Estas dos posiciones contrapuestas ayudarán a enmarcar las actuaciones del Estado, por una parte, y, por otra, las del Gobierno de la Generalitat de Cataluña en el procés independentista. El prof. Bayona Rocamora ${ }^{15}$, Letrado mayor del Parlamento de Cataluña, concreta la fundamentación de uno y otro. El Estado sostiene que los principios democrático y de legalidad son las dos caras de una misma moneda porque «la democracia es la que crea la legalidad a partir de la actuación de los representantes parlamentarios y la legalidad es legítima por el hecho de ser el fruto o el resultado del ejercicio de la democracia».

Por el contrario, el Gobierno de la Generalitat y los grupos parlamentarios que lo apoyan sostienen la contraposición de estos principios «a partir de la constatación de (...) que el Estado español mantiene formas autoritarias (postfranquistas) que lo convertirian en no democrático...»

En su sesión del 26 de julio de 2017, El Parlamento de Cataluña aprobó la modificación de 25 artículos de su Reglamento al que se le añadieron otros 6 . El nuevo art. 135.2 establece:

«2.-El grupo parlamentario promotor de una proposición de ley puede solicitar su tramitación por el procedimiento de lectura única. Corresponde al Pleno del Parlamento acordarla, a propuesta de la Mesa, oída la Junta de Portavoces o a iniciativa de ésta, siempre que la proposición de ley cumpla los requisitos establecidos por el apartado 1(si la naturaleza del proyecto lo aconseja o la simplicidad de la formulación lo permite). 3.-El debate de la iniciativa legislativa en lectura única se sujeta a las normas establecidas para los debates de totalidad; finalmente el conjunto de la iniciativa se somete a una sola votación.

El texto anterior de la norma exigía de la unanimidad de los grupos parlamentarios y esa exigencia era precisamente la que se quería modificar. La introducción de este apartado 2 supone la viabilidad de aprobar un proyecto de ley sin comparecencias ni debate en comisión y ponencia, además de excluir el derecho a formular enmiendas. Fue el atajo del grupo parlamentario de Junts pel si para aprobar los proyectos de ley de desconexión del Estado sin debate y en una única sesión.

Dos días después, el Presidente Gobierno anunció la interposición de un recurso de inconstitucionalidad ${ }^{16}$ con petición de suspensión ex art. 161.2 de la Constitución por supuesta vulneración del principio de participación de los arts. 23. 2 de la Constitución y 29 del Estatuto de Autonomía. Advirtió el prof. Punset Blanco ${ }^{17}$

14 Roberto Gargarella (2003): «La última carta. El derecho de resistencia en situaciones de alienación legal» en Roberto Saba (edtor.): La violencia y Derecho. Seminario en Latinoamérica de Teoría Constitucional y Política. Universidad de Palermo. Buenos Aires.

15 Antoni Bayona Rocamora (2017): «El futur polític de Catalunya: el paper del Parlament» en Revista Catalana de Dret Públic, n. ${ }^{\circ}$ 54. Escola d'Administració Pública de Catalunya. Barcelona, pp. 1 a 23.

${ }^{16}$ Recurso de inconstitucionalidad n. ${ }^{\circ}$ 4062/2017. B.O.E n. ${ }^{\circ} 182$ de 1 de agosto de 2017.

17 Ramón Punset Blanco (2017): «De nuevo ante la "Catalonia infelix" en Diario de Mallorca, 9 de agosto de 2017. 
que el Tribunal Constitucional debería barajar los precedentes del Auto 9/2012 sobre la tramitación del proyecto de reforma constitucional del art. 135 y de la Sentencia 238/2012 sobre la tramitación en lectura única del proyecto de reforma de la Ley orgánica del Poder Judicial. Mucho después se comprobó que estaba en lo cierto y en su Sentencia 139/2017 de 29 de noviembre de 2017 el T. C. declaró constitucional el nuevo art. 135.2 del Reglamento interpretado en los términos establecidos en el fundamento jurídico 8 , en el sentido de que su redacción no significa que excluya la posibilidad de articular un trámite de proposición de enmiendas y debate sobre ellas. El Tribunal sostiene que el silencio del precepto respecto al trámite de enmiendas debe entenderse tan solo como una falta de previsión normativa, de modo que en aplicación del art. 23.2 de la Constitución, conmina al Parlamento de Cataluña para regular la fase de enmiendas en la tramitación del procedimiento de lectura única.

En dos muy broncas sesiones celebradas el 6 y el 7 de septiembre de 2017, por el procedimiento de urgencia, el Parlamento de Cataluña aprobó la ley del referendo de autodeterminación y la ley de transitoriedad jurídica y fundacional de la república. En el articulado de la primera se establece que el pueblo de Cataluña es un sujeto político soberano (art. 2), la prevalencia jerárquica de esta ley sobre cualquier otra norma (art. 3) y la creación de una sindicatura electoral (arts. 17 y ss.).

Con el rango de norma suprema del ordenamiento jurídico catalán, la ley de transitoriedad se aprobó por el plazo de un año en el que debería ser sustituida por una Constitución de la República. El Presidente de la Generalitat será el Jefe del Estado. El Tribunal Superior de Justicia de Cataluña se convertirá en el Tribunal Supremo con una Sala Superior de Garantías con funciones de tribunal constitucional. La Generalitat pasa a ser la única autoridad tributaria con capacidad para gestionar todos los tributos en Cataluña. En sus artículos 85 a 89 se regula la apertura de un proceso constituyente que constaría de tres fases: Un Foro Social Constituyente conformaría un proceso participativo de base ciudadana; la convocatoria de elecciones constituyentes; y un plebiscito de ratificación de la nueva Constitución.

El Gobierno reaccionó instando al Fiscal General para que interpusiese sendas querellas contra el Govern de la Generalitat y contra los miembros de la Mesa del Parlament. Y coetáneamente acudió al Tribunal Constitucional para instar un recurso de inconstitucionalidad frente a la Ley del referendo e impugnar los decretos de convocatoria ${ }^{18}$. Por último el Tribunal admitió a trámite el incidente de ejecución de la sentencia n. ${ }^{\circ} 259 / 2015$ en relación a la ley de transitoriedad y fundacional de la república ${ }^{19}$ frente a la que asimismo el 12 de septiembre admitió el recurso de inconstitucionalidad instado por el Gobierno.

18 En fecha del 24 de octubre de 2017, es decir 3 días antes de la aprobación por el Senado de las medidas del art. 155, el Tribunal Constitucional dictó la STC 114/2017, por la que se declaró la inconstitucionalidad y nulidad de la Ley catalana 19/2017 del referéndum de autodeterminación.

19 ATC 124/2017 de 19 de septiembre. 
En fin y no obstante la suspensión acordada por el Tribunal Constitucional, el dictamen emitido por el Consell de Garanties Estatutaries y la declaración de la Comisión europea ${ }^{20}$, la fecha del 1 de octubre de 2017 muchos centenares de miles de ciudadanos acudieron a sus colegios electorales para responder a la siguiente pregunta: ¿Quiere que Cataluña sea un estado independiente en forma de república? La Fiscalía del Tribunal Superior de Justicia de Cataluña solicitó de los cuerpos de seguridad que incautasen las urnas, las papeletas y demás material relacionado con el referéndum. El cuerpo de los Mossos d'Esquadra se mostró mucho menos contundente que la Guardia Civil y la Policía Nacional. De hecho, las duras cargas policiales de los cuerpos nacionales, con varias decenas de personas que precisaron atención médi$\mathrm{ca}$, han sido difundidas e instrumentalizadas por la Generalitat para acusar al Estado de autoritarismo antidemocrático. El referéndum careció de las garantías propias de una consulta democrática: campaña plural, censo contrastado, urnas precintadas, impresión oficial de las papeletas, controles que asegurasen un solo voto por elector, ausencia de una junta electoral independiente, falta de un proceso contencioso de los resultados, etc. Ello no obstante, cinco días después, el Conseller de Presidencia Jordi Turull proclamó la victoria de los votos afirmativos, contabilizando un total de 2. 262.424 papeletas con 2.020.144 votos por el «sí» y 176.565 votos por el «no», con una participación del 43,03\%.

El 10 de octubre el Presidente Puigdemont intervino en el pleno del Parlament para proclamar los resultados favorables del referéndum. A continuación manifestó asumir «el mandato de que Cataluña se convierta en un Estado independiente en forma de república», si bien propuso que «el Parlamento suspenda los efectos de la declaración de independencia para que en las próximas semanas emprendamos el diálogo». Ya fuera de la sede parlamentaria, los miembros del Gobierno y los parlamentarios de los partidos independentistas suscribieron la proclamación de la nueva República catalana.

Al día siguiente, el Gobierno central requirió formalmente a la Generalitat para que acatase el orden constitucional. El President Puigdemont no atendió el requerimiento y la Mesa del Parlament convocó plenario para el 21 de octubre de 2017 en el que se votó la «DUI» (Declaración unilateral de independencia) y se proclamó la República Catalana.

Ese mismo día, el Consejo de Ministros cursó al Senado la petición de aplicar el art. 155. Las medidas fueron aprobadas por el Senado el 27 de octubre. Todo en menos de un trimestre.

Permítaseme advertir de una paradoja. Tal vez sea este precepto el único que los medios de comunicación citan por su número sin necesitar especificar que es un precepto de la Constitución española. Nunca antes un precepto constitucional había alcanzado tanta celebridad. Y, sin embargo, la Doctrina apenas le ha dedicado media docena de estudios

${ }^{20}$ http://europa.eu/rapid/press-release_STATEMENT-17-3626_es.htm 


\section{EL ART. 155 Y LA TENSIÓN REGIONAL. MODELOS DE DERECHO COMPARADO}

La configuración del Estado autonómico en la Constitución responde a un secular problema territorial. Se intentó resolver en la Constitución de 1931 como también en la de 1978. Atiende a unas raíces históricas muy profundas. Tanto en Cataluña como en el País Vasco los resultados electorales son muy diferentes del resto del Estado y favorecen a partidos políticos nacionalistas. Los programas de estos partidos son invariablemente reivindicativos y reclaman incrementar competencias y recursos económicos.

Y hete aquí donde aparece la tensión territorial entre cualquier Estado compuesto y sus entes territoriales. La Constitución del 78 fija en el artículo 2 la piedra angular de esta relación: De una parte, la indivisible unidad de la Nación española; y de otra, el derecho a la autonomía de nacionalidades y regiones. La distribución de competencias rige por un sistema de doble lista (las competencias exclusivas del Estado en el art. 149; las potestativas de las Comunidades Autónomas en el art. 148) con tres cláusulas de cierre (residual a favor de las Comunidades Autónomas; de prevalencia de las normas estatales en caso de conflicto; y de supletoriedad del Derecho estatal). Y finalmente un procedimiento ante el Tribunal Constitucional para la resolución de los conflictos de competencias entre el Estado y las Comunidades Autónomas (art. 161.1.c).

El art. 155 está previsto para un escenario diferente cuando una Comunidad Autónoma no se atiene a las reglas constitucionales antes expuestas y opta por desobedecer la Constitución. Para afrontar esta situación de crisis, el Derecho comparado de los Estados compuestos ha configurado la llamada coerción estatal, es decir la atribución a algún órgano constitucional de facultades coercitivas excepcionales. A este respecto, el prof. Cruz Villalón ${ }^{21}$ escribe: «Ningún Estado federal ni, por extensión, ningún Estado «compuesto» puede subsistir si no dispone de la posibilidad de imponer a las unidades territoriales autónomas que lo integran, si es preciso por la fuerza, el cumplimiento de las obligaciones derivadas del ordenamiento general del Estado».

En el Derecho Comparado las fórmulas son muy variadas. Todas parten de dos principios esenciales: el de unidad y el de lealtad. El de unidad es consustancial a uno de los elementos propios del Estado cual es la soberanía. Sin una soberanía única de la nación no existe Estado $^{22}$.Y el de lealtad que implica que cada comunidad federada ejerza las competencias que le son propias atendiendo además al interés general del Estado ${ }^{23}$. De

${ }^{21}$ Pedro Cruz Villalón (1981): «La protección extraordinaria del Estado» en Alberto Predieri y Eduardo García de Enterría: «La Constitución española de 1978». Ed. Civitas, Madrid, pp. 689 a 717.

${ }^{22}$ Georg Jellinek (1896): Über Staatsfagmente. Verlag von Gustav Koester. Heilderberg. Traducción al español: Fragmentos de Estado. Ed. Civitas. Madrid 1978.

${ }^{23}$ V. sobre la «lealtad constitucional» las SSTC 25/1981, 96/1986, 247/2007. Paloma Biglino Campos (2004): «La lealtad constitucional en el Estado de las Autonomías» en Revista Jurídica de Castilla y León, n..$^{\circ}$ extraordinario. Junta de Castilla y León. Valladolid, pp. 51 a 74. Francisco Sosa Wagner 
hecho, el prof. Álvarez Álvarez ${ }^{24}$ invoca la Doctrina alemana para sostener que el art. 155 es una disposición de lealtad autonómica que resulta de aplicación en supuestos extraordinarios. Los profs. Vírgala Foruria ${ }^{25}$ y Gómez Orfanel ${ }^{26}$ han sistematizado los modelos en los siguientes grupos:

a) La intervención federal a petición de un Estado miembro.

— La Constitución americana de 1787, art. IV.4 $4^{27}$ (Los Estados Unidos garantizarán a todo Estado comprendido en esta Unión una forma republicana de gobierno y protegerán a cada uno en contra de invasiones, así como contra los disturbios internos, cuando lo soliciten la legislatura o el ejecutivo (en caso de que no fuese posible reunir a la legislatura) ${ }^{28}$. El conflicto conocido como Little Rock Nine constituye un espléndido ejemplo. Contraviniendo la Sentencia «Brown v. Board of Education, 347 U.S. 483 (1954)» de la Corte Suprema contra la segregación racial en Topeka, el Gobernador de Arkansas Orval Faubus ordenó a las tropas de la Guardia Nacional impedir el acceso de nueve alumnos negros en la Central High School de Littel Rock. Por su parte, el Presidente Eisenhower reaccionó enviando tropas del Ejército para garantizar el acceso de aquellos alumnos negros.

—Constitución argentina de 1994, art. 629: «El Gobierno federal interviene en el territorio de las provincias para garantir la forma republicana de gobierno, 0 repeler invasiones exteriores, y a requisición de sus autoridades constituidas para sostenerlas o restablecerlas, si bubiesen sido depuestas por la sedición, o por invasión de otra provincia.»

- Constitución mejicana de 1917, art $119^{30}$ (reformado en enero 2016): «Los Poderes de la Unión tienen el deber de proteger a las entidades federativas contra toda invasión o violencia exterior. En cada caso de sublevación o tras-

(2008): «Estatuto de autonomía y fragmentación de la Administración. La lealtad federal» en Anales de la Cátedra Francisco Suárez, n. ${ }^{\circ}$ 42. Universidad de Granada, pp. 73 a 92.

${ }^{24}$ Leonardo Álvarez Álvarez (2008): «La función de la lealtad en el Estado autonómico» en Teoría y Realidad Constitucional, n. ${ }^{\circ} 22$. UNED, Madrid, p. 523.

25 Eduardo Vírgala Foruria (2005): «La coacción estatal del artículo 155 de la Constitución» en Revista Española de Derecho Constitucional, n. ${ }^{\circ}$ 73, enero-abril 2005. Madrid, pp. 55 a 109.

${ }^{26}$ Germán Gómez Orfanel (2015): «La coerción federal en el Derecho comparado», en Cuadernos de Derecho Público, n. ${ }^{\circ}$ 26. I.N.A.P., Madrid, pp. 41 a 60.

27 Deborah Jones Merritt (1988): «The Guarantee Clause and State Autonomy: Federalism for a Third Century» en Columbia Law Review. Vol. 88, no. 1. Columbia University, pp. 1 a 78.

28 «The United States shall guarantee to every State in this Union a Republican Form of Government, and shall protect each of them against Invasion; and on Application of the Legislature, or of the Executive (when the Legislature cannot be convened) against domestic Violence.»

29 Guillermo Becerra Ferrer (1965): «La intervención federal en las provincias en el Derecho Constitucional argentino» en Revista de Estudios Políticos, n. ${ }^{\circ}$ 144. C.E.P. Madrid, pp. 153 a 165.

30 José A. González Fernández (1975): La intervención en los Estados. Escuela Libre de Derecho. México. 
torno interior, les prestarán igual protección, siempre que sean excitados por la Legislatura de la entidad federativa o por su Ejecutivo, si aquélla no estuviere reunida.»

—Constitución australiana de 1901, art. 119 ${ }^{31}$ : «El Commonwealth protegerá cada Estado de invasión y, en la aplicación del Poder Ejecutivo del Estado, de la violencia local» ${ }^{32}$

b) La disolución directa de los órganos constitucionales.

- Constitución italiana de 1947, art. 12633: «Se acordarán por decreto razonado del Presidente de la República la disolución del Consejo Regional y la remoción del Presidente de la Junta que hayan realizado actos contrarios a la Constitución o incurrido en violaciones graves de la ley. Podrán asimismo la disolución y la remoción ser acordadas por razones de seguridad nacional. El decreto se adoptará, oída una Comisión de diputados y senadores constituida para las cuestiones regionales, según las normas establecidas por ley de la República... ${ }^{34}$. Este precepto fue posteriormente desarrollado en el art. 50 de la Ley n. 62 de 10 de febrero de 1953.

- Constitución austríaca de 1920, art. 10035: "Toda Dieta Regional podrá ser disuelta, a instancias del Gobierno federal y con la aquiescencia del Consejo federal, por el Presidente federal. La conformidad del Consejo Federal se acordará en presencia de la mitad de sus componentes y por mayoría de dos tercios de los votos emitidos. No podrán tomar parte en la votación los representantes del Estado cuya Dieta Regional se trate de disolver.» ${ }^{36}$

31 Peta Stephenson (2015): «Fertile ground for federalism?: Internal security, the states and section 119 of the Constitution» en Federal Law Review, vol. 43 n. ${ }^{\circ}$ 2. Australian National University, Camberra, pp. 289 a 312.

32 «The Commonwealth shall protect every State against invasion and, on the application of the Executive Government of the State, against domestic violence.»

33 Marco Mancini: «L'art. 126 Cost. Novellato, ovverosia di una modifica apparentemente marginale, ma in tealtá gravida da implicazioni» en Rivista di Diritto Pubblico Italiano comparato, europeo, no. 22. Ed G. Giappichelli, Torino 2016, pp. 2 a 27.

34 «Con decreto motivato del Presidente della Repubblica sono disposti lo scioglimento del Consiglio regionale e la rimozione del Presidente della Giunta che abbiano compiuto atti contrari alla Costituzione o gravi violazioni di legge. Lo scioglimento e la rimozione possono altresi essere disposti per ragioni di sicurezza nazionale. Il decreto è adottato sentita una Commissione di deputati e senatori costituita, per le questioni regionali, nei modi stabiliti con legge della Repubblica.

35 Peter Pernthaler y Fried Esterbauer (1980): «Der Föderlalismus» en Herbert Schambeck: Das östereichische Bundes-Verfassungsgesetz und Entwicklung. Dunker \& Humbolt, Berlín, pp. 325 a 349.

36 «Jeder Landtag kann auf Antrag der Bundesregierung mit Zustimmung des Bundesrates vom Bundespräsidenten aufgelöst werden; eine solche Auflösung darf jedoch nur einmal aus dem gleichen Anlass verfügt werden. Die Zustimmung des Bundesrates muss bei Anwesenheit der Hälfte der Mitglieder und mit einer Mehrheit von zwei Dritteln der abgegebenen Stimmen beschlossen werden. An der Abstimmung dürfen die Vertreter des Landes, dessen Landtag aufgelöst werden soll, nicht teilnehmen.» 
—Constitución portuguesa de 1976, art. 2347: «Los órganos de las regiones autónomas podrán ser disueltos o suspendidos por el Presidente de la República por haber cometido actos contrarios a la Constitución, oídos el Consejo de la Revolución y la Asamblea de la República. ${ }^{38}$

c) La coerción federal.

Es el modelo de la Constitución española, tomado en gran medida de la Ley Fundamental de Bonn, en cuyo art. 37, Bundeszwang, ${ }^{39}$ o coerción federal establece: "(1) Si un Land no cumpliere los deberes federales que la Ley Fundamental u otra ley federal le impongan, el Gobierno Federal, con la aprobación del Bundesrat, podrá adoptar las medidas necesarias para obligar al Land al cumplimiento de dichos deberes por vía coactiva federal. (2) Para la ejecución de las medidas federales coactivas, el Gobierno Federal o su representante tiene el derecho de impartir instrucciones a todos los Länder y a las autoridades de los mismos.»

De la comparación de este texto con el del art. 155 se infieren dos diferencias importantes: La primera se refiere al supuesto de hecho para que el Gobierno use de este precepto que no se limita como en el caso alemán al incumplimiento de las obligaciones constitucionales y legales, sino también a una actuación de la Comunidad Autónoma que atente gravemente al interés general de España. La segunda es de procedimiento porque en el caso español se reclama una exigencia previa cual es un requerimiento al Presidente de la Comunidad Autónoma.

Adviértase, por otra parte, que además de la coerción federal del art. 37, la Ley Fundamental de Bonn dispone de otros preceptos que regulan las relaciones entre el Estado y los Länder:

El art. 84 regula en sus tres últimos apartados la Bundesaufscht (supervisión federal), es decir la supervisión por el Gobierno federal de la ejecución de las leyes federales por los Estados mediante comisionados. Si aun así no se hubiesen subsanado las deficiencias de ejecución de las leyes federales, el Gobierno federal puede solicitar la intervención del Consejo federal. Y, en fin, el Gobierno federal, con el asentimiento del Bundesrat, podrá mediante una ley federal atribuir las facultades necesarias para la ejecución de las leyes federales e incluso dictar instrucciones singulares para las autoridades regionales.

37 Vita Moreira, Jose Joaquim Gomes Cantilho (2014): «Constituçâo da repubica Portuguesa Anotada». Ed. Coimbra. Coimbra, vol II.

38 «As Assembleias Legislativas das regiões autónomas podem ser dissolvidas pelo Presidente da República, ouvidos o Conselho de Estado e os partidos nelas representados.»

39 «(1) Wenn ein Land die ihm nach dem Grundgesetze oder einem anderen Bundesgesetze obliegenden Bundespflichten nicht erfüllt, kann die Bundesregierung mit Zustimmung des Bundesrates die notwendigen Maßnahmen treffen, um das Land im Wege des Bundeszwanges zur Erfüllung seiner Pflichten anzuhalten. (2) Zur Durchführung des Bundeszwanges hat die Bundesregierung oder ihr Beauftragter das Weisungsrecht gegenüber allen Ländern und ihren Behörden.» 
El art. 91 regula la intervención de la Federación: Para el restablecimiento de la seguridad o el orden público, o para la defensa frente a una amenaza contra la libertad o la democracia, un Land puede reclamar el apoyo del Cuerpo Federal de Protección de Fronteras o de las Fuerzas Armadas. Y añade que si el Estado afectado no combatiese el peligro, el Gobierno federal podrá someter a la policía de ese Estado y a las de otros Estados.

Y, por último, conforme al art. 87.a.4, el Gobierno podría intervenir directamente, sin la previa reclamación del Land, para prevenir un peligro inminente para la existencia, la libertad o la democracia de la Federación o para luchar contra sediciosos organizados y militarmente armados.

De estos preceptos se concluye que la Ley Fundamental de Bonn participa de dos modelos: de la intervención federal a petición de un Estado miembro, al modo de la Constitución americana; y de la coerción federal como la Constitución española.

Es lugar común que los autores citen la Teoría General del Estado ${ }^{40}$ de Hans Kelsen para reproducir el listado de actuaciones que incluiría la coerción federal. Tal vez medidas como las de requisar alimentos o fusilar a los sediciosos hayan quedado obsoletas en favor de otras como podrían ser la intervención de la tesorería o la incautación de las bases de datos informáticas.

\section{LA INELUDIBLE REFERENCIA A LA COERCIÓN FEDERAL EN ALEMANIA. EL ART. 155 Y SU COMPARACIÓN CON EL 37 DE LA LEY FUNDAMENTAL DE BONN}

Sin duda por la influencia que ha tenido en la redacción del art. 155 de la Constitución española, los autores inciden en los avatares históricos de la coerción federal alemana. El antecedente inmediato es el del art. 48 de la Constitución de Weimar (1919) y su aplicación en el Golpe Prusiano de 1932. Este precepto constitucional establecía la facultad del Presidente de recurrir a las Fuerzas Armadas en dos supuestos: cuando algún Estado miembro no cumpliese la Constitución; o por grave riesgo de la seguridad y el orden público (1.-Si un Estado no cumple los deberes que le impone la Constitución o las leyes del Imperio el Presidente de éste podrá obligarle a ello, con ayuda de la fuerza armada. 2.-Cuando se hayan alterado gravemente o estén en peligro la seguridad y el orden públicos en el Imperio, el Presidente puede adoptar las medidas indispensables para el restablecimiento de los mismos, incluso en caso necesario con ayuda de la fuerza armada. Con este fin puede suspender temporalmente en todo o en parte los derechos fundamentales fijados en los artículos 114, 115, 117, 118, 123, 124 Y 153.») $)^{41}$

${ }^{40}$ Hans Kelsen (1925): Allgemeine Staatslebre. M. Gehlen. Berlín. Traducción española «Teoría General del Estado». Ed. Coyoacan, México 2008.

41 «(1) Wenn ein Land die ihm nach der Reichsverfassung oder den Reichsgesetzen obliegenden Pflichten nicht erfüllt, kann der Reichspräsident es dazu mit Hilfe der bewaffneten Macht anhalten. 
El Presidente Hindenburg se fundamentó en este precepto para dictar la Ordenanza de 20 de julio de 1932. Destituyó a Otto Braun de su cargo de Presidente del Gobierno prusiano, al tiempo que nombró a Franz von Papen para el cargo de Comisario del Reich en Prusia, además de acordar la suspensión de los derechos constitucionales de los ciudadanos. La Ordenanza fue objeto de una sentencia histórica, la StGH (43) (Preussen c. Reich) de 25 de octubre de 1932.El Tribunal resolvió que esas medidas no podían tener fundamento en ningún incumplimiento de la legalidad imputable a Prusia; pero que, sin embargo, encontraban acomodo en el supuesto de grave peligro para la seguridad y el orden público del Reich. Poco después, Adolf Hitler fue nombrado Canciller el 30 de enero de 1933. El Presidente Hindenburg dictó una segunda Ordenanza el 6 de febrero de 1933 para privar de competencias al Gobierno prusiano por razones de orden público. El Tribunal estatal fue disuelto antes de poder resolver el recurso que las autoridades prusianas instaron frente a esta segunda Ordenanza.

En mi opinión, el modelo de la Constitución de Weimar se asemeja al modelo de dictadura constitucional francés ${ }^{42}$. En una clasificación que todavía está vigente, Pedro Cruz Villalón ${ }^{43}$ distinguió dos modelos de Derecho de excepción: la dictadura constitucional (p. e. la Constitución francesa de 1958) y el estado excepcional (p. e., el art. 116 de la Constitución española de 1978).

Karl Loewenstein ${ }^{44}$ define la dictadura constitucional como «la sustitución temporal de la técnica que distribuye el poder en las manos del detentador gubernamental, así como la suspensión de los normales controles interorgánicos de la asamblea frente al Ejecutivo durante la duración del período de excepción». Sin duda el modelo más característico de dictadura constitucional es el establecido en el art. 16 de la Constitución francesa de 1958 ( «Cuando las instituciones de la República, la independencia de la Nación, la integridad de su territorio o el cumplimiento de sus compromisos internacionales están amenazados de una manera grave e inmediata, y el funcionamiento regular de los poderes públicos constitucionales esté interrumpido, el Presidente de la República tomará las medidas exigidas para tales circunstancias, previa consulta oficial con el Primer Ministro, los presidentes de las asambleas y el Consejo Constitucional...» $)^{45}$.

(2) Der Reichspräsident kann, wenn im Deutschen Reiche die öffentliche Sicherheit und Ordnung erheblich gestört oder gefährdet wird, die zur Wiederherstellung der öffentlichen Sicherheit und Ordnung nötigen Maßnahmen treffen, erforderlichenfalls mit Hilfe der bewaffneten Macht einschreiten. Zu diesem Zweck darf er vorübergehend die in den Artikeln 114, 115, 117, 118, 123, 124 und 153 festgesetzten Grundrechte ganz oder zum Teil außer Kraft setzen.»

${ }^{42}$ José M. ${ }^{a}$ Lafuente Balle $(1989,1990)$ : «Los estados de alarma, excepción y sitio» en Revista de Derecho Político, n. 30 , pp. 24 a 54 y n..$^{\circ} 31$, pp. 28 a 67. UNED, Madrid.

${ }^{43}$ Pedro Cruz Villalón (1984): Estados excepcionales y suspensión de garantías. Ed. Tecnos, Madrid.

${ }^{44}$ Karl Loewenstein (1976): Teoría de la Constitución. Ed. Ariel. Barcelona, p. 285.

45 «Lorsque les institutions de la République, l'indépendance de la nation, l'intégrité de son territoire ou l'exécution de ses engagements internationaux sont menacées d'une manière grave et immédiate et que le fonctionnement régulier des pouvoirs publics constitutionnels est interrompu, le Président de la République prend les mesures exigées par ces circonstances, après consultation officielle du Premier ministre, des présidents des assemblées ainsi que du Conseil constitutionnel...» 
El Derecho de excepción establecido en el art. 16 de la Constitución francesa regula tanto los presupuestos como los efectos para la atribución al Presidente de los poderes excepcionales constitucionalizados. Sucede que Francia no es un Estado federal y que entre los presupuestos no se incluye la desobediencia de algún ente territo-

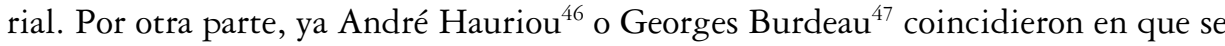
trata de un poder discrecional del Presidente. Así se confirmó con motivo de la célebre Decisión Rubin de Servens de 2 de marzo de 1962. A resultas del levantamiento de cuatro generales en Argelia, El Presidente Charles de Gaulle invocó el art. 16 de la Constitución y promulgó el Arrêt Rubin de Servens. En este Decreto acordó la jurisdicción de los tribunales militares y la suspensión de los derechos constitucionales. El Consejo de Estado ${ }^{48}$ dictaminó que las decisiones que el Presidente de la República adopte en ejercicio de los poderes que le atribuye el art. 16 no están sujetas a control jurisdiccional.

El modelo de la Constitución de Weimar responde a la lógica de la dictadura constitucional. Como en la Constitución francesa de 1958, el supuesto de hecho es un peligro grave para la seguridad o el orden público cuya defensa corresponde a los poderes regulares del Estado. Y, sobre todo, en ambos casos, el efecto es la atribución al Presidente de facultades absolutamente excepcionales para adoptar cuantas medidas sean precisas a fin de restablecer el orden constitucional, inclusive la suspensión de los derechos fundamentales y la intervención militar.

Insisten los constitucionalistas que han estudiado el art. 155 en invocar la influencia alemana y retrotraerse hasta la Constitución de Weimar. Sin embargo, mientras que el sistema político español es parlamentarista, el modelo weirmariano es el de un Presidente elegido por sufragio universal y, por consiguiente, con legitimidad democrática directa incluso para imponer la dictadura constitucional. La influencia alemana sería posterior y resultaría de la Ley Fundamental de Bonn de 1949.

La coerción federal aparece regulada en el art. 37: (1) Si un Estado no cumpliere los deberes federales que la Ley Fundamental u otra ley federal le impongan, el Gobierno Federal, con la aprobación del, podrá adoptar las medidas necesarias para obligar al Land al cumplimiento de dichos deberes por vía coactiva federal.(2) Para la ejecución de las medidas federales

46 André Hauriou (1966): Droit Constitutionnel et institutions politiques. Ed. Montchrestien, Paris. Traducción al español, Derecho Constitucional e Instituciones Políticas. Ed. Ariel, Barcelona 1980, pp. 627 a 631

47 Georges Burdeau (1977): Droit Constitutionnel et institutions politiques. Librairie Générale de Droit et Jurisprudence, Paris. Traducción al español Derecho Constitucional e Instituciones Políticas. Ed. Nacional, Madrid 1981, pp. 803 a 804.

48 N. ${ }^{\circ} 55049$ 55055: «... cette décision présente le caractère d'un acte de gouvernement dont il n'appartient au Conseil d'Etat ni d'apprécier la légalité, ni de contrôler la durée d'application ; que ladite décision a eu pour effet d'habiliter le Président de la République à prendre toutes les mesures exigées par les circonstances qui l'ont motivée et, notamment, à exercer dans les matières énumérées à l'article 34 de la Constitution le pouvoir législatif et dans les matières prévues à l'article 37 le pouvoir réglementaire...» 
coactivas, el Gobierno Federal o, eventualmente, su comisionado tiene el derecho de impartir instrucciones a todos los Länder y a sus autoridades» ${ }^{49}$.

El supuesto de hecho de la coerción federal alemana es el incumplimiento por un Land de los deberes federales, es decir de sus obligaciones constitucionales. La Doctrina alemana identifica este incumplimiento con la falta de lealtad federal. La legitimación para iniciar el proceso compete al Gobierno federal mediante una decisión política que debe cumplimentar ciertos requisitos: concreción del incumplimiento, determinación de las medidas, aprobación por la mayoría absoluta del Bundesrat. Esta decisión es discrecional y, por ende, irrecurrible ante la Jurisdicción. Entre las medidas que contemplan los constitucionalistas se incluyen la intervención financiera, la ejecución sustitutoria de la actividad legislativa o ejecutiva y la intervención de la policía del Land. Ahora bien, se excluye la suspensión del régimen federal de los Länder porque así se establece en la cláusula de intangibilidad del art. 79.3 sobre la reforma constitucional ( $N$ No está permitida ninguna modificación de la presente Ley Fundamental que afecte la organización de la Federación en Länder...»). ${ }^{50}$

No es discutible la influencia del art. 37 L.F.B. en los constituyentes españoles, A este respecto y glosando el debate constituyente, el prof. Vírgala Foruria ${ }^{51}$ escribe: "...España sin constituirse en Estado federal tiene en cuanto al nivel de descentralización territorial más semejanza con aquel que con los Estados regionales europeos, por lo que se postula la introducción de una institución como la coacción federal, propia del Estado europeo más descentralizado hasta ese momento como era la República Federal de Alemania...».

Las similitudes son evidentes como las diferencias cruciales, a saber:

1. A Aunque la coerción estatal se sujeta al voto por mayoría absoluta tanto del Bundesrat en la L.F.B. como del Senado en la Constitución española, la configuración de una y otra cámara son diferentes. El Senado no está configurado como una cámara de representación territorial sino como de segunda lectura.

2. ${ }^{a}$ En el art. 155 se incluye el interés general, además de la desobediencia, como supuesto de hecho para la declaración.

49 (1) Wenn ein Land die ihm nach dem Grundgesetze oder einem anderen Bundesgesetze obliegenden Bundespflichten nicht erfüllt, kann die Bundesregierung mit Zustimmung des Bundesrates die notwendigen Maßnahmen treffen, um das Land im Wege des Bundeszwanges zur Erfüllung seiner Pflichten anzuhalten.

(2) Zur Durchführung des Bundeszwanges hat die Bundesregierung oder ihr Beauftragter das Weisungsrecht gegenüber allen Ländern und ihren Behörden.

50 John J. Vogel (2001): «El régimen federal de la Ley Fundamental» en Benda, Maihofer, Vogel, Hesse, Heyde: Manual de Derecho Constitucional. Ed. Marcial Pons, Madrid 2001, pp. 613 a 676. Y Enoch Albertí (1986): Federalismo y cooperación en la República federal alemana. Centro de Estudios Constitucionales, Madrid, pp. 218 a 221.

51 Eduardo Vírgala Foruria (2005): op. cit., p. 78. 
3. ${ }^{a}$ El art. 155 exige el requisito del previo requerimiento al Presidente de la Comunidad Autónoma para el que no fija ningún plazo de respuesta.

$4{ }^{a} \mathrm{El}$ art. 155 no especifica las leyes objeto de desobediencia mientras que el art. 37 L.F.B. concreta que son las federales.

\section{LA STGC DE 5 DE MARZO DE 1936}

Como sucede con el art. 155 de la Constitución española, el art. 37 de la Ley Fundamental de Bonn carece de precedentes. Pero al igual que la doctrina alemana con el golpe prusiano de 1932 durante la vigencia de la Constitución de Weimar, también el constitucionalismo español rememora el caso de la disolución de la Generalitat catalana en 1934 estando en vigor la Constitución de $1931^{52}$.

Dos elecciones habrían de escenificar el conflicto. La primera fue la del 20 de noviembre de 1932 al Parlamento de Cataluña que ganó Esquerra Republicana de Catalunya con mayoría absoluta. Francesc Maciá y, tras su fallecimiento, Lluis Companys fueron elegidos para la Presidencia de la Generalitat. Justo un año después, el 19 de noviembre de 1933, las elecciones a Cortes Generales se saldaron con la victoria de la C.E.D.A., si bien el Presidente Alcalá Zamora encargó la formación de Gobierno a Alejandro Lerroux, líder del Partido Radical, que conformaría un gabinete de coalición con otros ministros de partidos de la izquierda.

A tan diferente signo político entre ambos gobiernos, se añadirán importantes litigios. El primero es la aprobación en el Parlamento catalán de la Llei de contractes de conreu de 11 de abril de 1934 que contemplaba el acceso de los campesinos a la propiedad de las tierras. El Tribunal de Garantías Constitucionales estimó el recurso del Gobierno presidido por el recién nombrado Ricardo Samper y declaró la nulidad de la ley por vulneración de competencias del Estado. Esta crisis dio lugar a la sustitución de Ricardo Samper nuevamente por Alejandro Lerroux que incluyó ministros cedistas de partidos agrarios en su cuarto gobierno.

La entrada de tres ministros de la C.E.D.A. en el gobierno provocó la espita para que el P.S.O.E y la U.G.T. convocasen una huelga general el 5 de octubre de 1934. El éxito de la convocatoria fue especialmente destacado en Asturias y Cataluña. La Aliança Obrera de Catalunya consiguió paralizar la ciudad de Barcelona no sin importantes problemas de orden público.

El Presidente Lerroux declaró el estado de guerra y la aplicación de la Ley de Orden Público en toda España; y, por su parte, el Presidente Companys da por rota toda relación con las que califica como instituciones republicanas falseadas y proclamó el Estado catalán. Por orden del Presidente Lerroux, el general Domingo

52 Josep Termes (1999): «De la Revolució de Setembre a la fi de la Guerra Civil (1868-1939)». Vol. 6 de la «Història de Catalunya» dirigida por Pierre Vilar. Edicions 62, Barcelona. Santos Juliá (1999): Un siglo de España. Política y sociedad. Ed. Marcial Pons. Madrid. 
Batet se enfrentó a varios grupos armados en la Rambla de Santa Mónica hasta alcanzar la Plaza de la República (actual Plaza de Sant Jaume) y ocupar la sede de la Generalitat con sus compañías de artillería. A las 7 de la mañana del 7 de octubre de 1934, el Presidente Companys fue detenido y, junto a sus ministros, encarcelado en el buque Uruguay. La rebelión se había controlado y la autonomía catalana fue suspendida. Una Ley de 2 de enero de 1935 atribuyó sus competencias administrativas a un Consejo de la Generalidad designado por el Gobierno. Un año después, con motivo de la victoria del Frente Popular en las elecciones del 16 y el 23 de febrero de 1936, el Decreto-Ley de 26 de febrero autorizó a que el Parlamento catalán reanudase su actividad.

Aquella Ley de 2 de enero de 1935 fue recurrida de inconstitucionalidad por el Presidente del Parlamento de Cataluña ante el Tribunal de Garantías Constitucionales. El recurrente alegó vulneración del Estatuto de Autonomía de Cataluña de 2 de enero de 1935 y del art. 11 de la Constitución sobre el derecho a la autonomía de las regiones y argumentó que la Ley de 2 de enero de 1935 constituía una alteración improcedente de las facultades de la Generalitat: un Gobernador general asumía las facultades del Presidente de la Generalitat y el Parlamento de Cataluña veía suspendidas sus facultades legislativas. La Sentencia de 5 de marzo de 1936 constituye una página del máximo interés. El Tribunal estimó el recurso por mayoría y argumentó razones materiales para fundamentar su fallo: «Si bien los Estatutos de autonomía previstos en la Constitución no son leyes de categoría constitucional, lo es el principio de autonomía de que nace, y es también cierto que el artículo 11 de la Constitución, relacionado con el siguiente, establece la previa exigencia de requisitos especiales y en el párrafo final del primero las confiere el carácter de leyes orgánicas del régimen político y administrativo del país e impone al Estado la obligación de reconocerlos y ampararlos como parte integrante de su ordenamiento jurídico. Y tal obligación envuelve y significa mucho más que el prescribir lo que al Estado incumbe en cuanto a todas las leyes vigentes como es la obligación de cumplirlas y hacerlas cumplir por todos los órganos adecuados, porque si se limitara su alcance a este natural, mínimo e inalienable contenido, no tendría sentido incluir esta obligación en el texto constitucional. Por esta razón y porque la organización del Estado debe tener la necesaria estabilidad, hay que entender destinado este precepto final del artículo 11 a garantizar el régimen de autonomía con prevenciones que en sí, como tal régimen de organización del país y en cuanto que implica reconocimiento de la personalidad de un núcleo político administrativo lo sustraigan a la paralización no autorizada por la Constitución».

Tal vez la coerción estatal sea consustancial al Estado compuesto ${ }^{53}$. Ello no obstante, lo cierto es que La Constitución española de 1931 padecía la laguna legal de carecer de un precepto que la regulase. Solo así se explica que la Sentencia no atendiese que la Ley de 2 de enero de 1935 se fundamentaba en la necesidad de remediar

53 Eduardo Vírgala Foruria (2005): op. cit. p. 75. 
una situación de objetivo incumplimiento de las funciones constitucionales y estatutarias propias del Gobierno catalán ${ }^{54}$.

La lectura de esta Sentencia constituye un importante precedente frente a aquellas voces que invocan el art. 155 para reclamar la suspensión de la autonomía catalana ante la continuada convocatoria de referendos secesionistas el 9 de noviembre de 2014 y el 1 de octubre de 2017.

\section{LA COERCIÓN ESTATAL DEL ART. 155.}

José M. ${ }^{a}$ Gil-Robles ${ }^{55}$ acertadamente enmarca la excepcionalidad del precepto cuando escribe: «...el artículo 155 no es norma excepcional si por tal se entiende un ius singulare, inspirada en principios contradictorios con los generales; pero sí instituye una forma de control excepcional, tomando este término como contrario a normal o habitual»

Todos los autores que han estudiado el art. 155 coinciden en destacar dos rasgos fundamentales del precepto: la discrecionalidad de la decisión gubernamental y la excepcionalidad de su aplicación como última ratio. La discrecionalidad del Gobierno, si bien sujeta a la aprobación de la mayoría absoluta del Senado. Y la excepcionalidad por respeto a la institución del autogobierno que los arts. 2 y 143 reconocen a las comunidades autónomas. Sobre estas dos premisas, las definiciones de la institución varían desde las meramente descriptivas a las que destacan su gravedad.

Entre las primeras, el prof. Alzaga Villaamil ${ }^{56}$ escribe que se trata de «un control político, centralizado en el Gobierno, unilateral a posteriori y en base a criterios de discrecionalidad política», si bien añade que no es ad pompam vel ostentationem. En el extremo contrario, el prof. Cruz Villalón ${ }^{57}$ se refiere a este precepto como «la decisión más trascendente de las previstas en la Constitución» y «el artículo más explosivo de la Constitución».

Menos contundente se muestra el prof. Vírgala Foruria ${ }^{58}$ cuando sostiene que solo sería aplicable muy excepcionalmente en caso de desobediencia expresa y contumaz a un proceso judicial previo que diese lugar a una Sentencia del Tribunal Constitucional ( «...que el TC bubiera admitido la suspensión de la tramitación de la Propuesta Ibarretxe en el Parlamento vasco y éste bubiera seguido tramitándola...»).

${ }^{54}$ Jesús García Torres (1984): «El artículo 155 de la Constitución española y principio constitucional de autonomía» en AA. VV.: Organización territorial del Estado (Comunidades Autónomas). Instituto de Estudios Fiscales, Madrid, Vol. II, p. 1244.

55 José M. ${ }^{a}$ Gil-Robles y Gil-Delgado (con la colaboración de Loreto Gil-Robles Casanueva) (1999): "Artículo 155. El control extraordinario de las Comunidades Autónomas» en Óscar Alzaga Villaamil (dir.): Comentarios a la Constitución española de 1978. Edersa, Madrid, p. 505.

${ }^{56}$ Óscar Alzaga Villaamil (2016): Comentario sistemático a la Constitución española de 1978. Ed. Marcial Pons. Madrid, pp. 676 a 678.

57 Pedro Cruz Villalón (1981): op. cit., p. 715.

${ }^{58}$ Eduardo Vírgala Foruria (2005): op. cit., pp. 81 y 82. 
Los acontecimientos de octubre y noviembre de 2017 han venido a dar la razón al diagnóstico de Eduardo Vírgala a propósito del llamado procés en Cataluña. La aplicación del art. 155 fue consecuencia de una desobediencia expresa y contumaz. El Parlamento de Cataluña decidió incumplir la STC 259/2015 como todas las anteriores (SSTC 103/2008, 31/2010, 42/2014). No conozco que en ninguna democracia de la O.C.D.E. exista un precedente como el de la Declaración del Parlamento de Cataluña 1/XI anunciando su desobediencia a los tribunales: «SEXTO._El Parlamento de Cataluña, como depositario de la soberanía y como expresión del poder constituyente, reitera que esta cámara y el proceso de desconexión democrática del Estado español no se supeditarán a las decisiones de las instituciones del Estado español, en particular del Tribunal Constitucional, que considera falto de legitimidad y de competencia...».

Consecuente con esta declaración, el Parlamento de Cataluña fue adoptando decisiones que fueron, una a una, declaradas inconstitucionales por el Tribunal Constitucional en otros tantos incidentes de ejecución de la STC 259/2015:

El ATC 141/2016 de 19 de julio anula La Resolución 5/XI de 20 de enero de 2016 por la que se crea una comisión parlamentaria para el estudio del proceso constituyente. El ATC 170/2016 de 6 de octubre anula la Resolución 263/XI de 27 de julio de 2016 que acuerda el inicio de un proceso constituyente ( El proceso constituyente constará de tres fases: una primera fase de proceso participativo, una segunda fase de desconexión con el Estado español y convocatoria de elecciones constituyentes para formar una Asamblea constituyente, que redactará un proyecto de constitución, y una tercera fase para la ratificación popular de la constitución por medio de referéndum») y la aprobación de unas leyes de desconexión del Estado que serían irrecurribles ante los tribunales ( Tras la fase de participación ciudadana, se completará la desconexión con la legalidad del Estado Parlamento de Cataluña y de un mecanismo unilateral de ejercicio democrático que servirá para activar la convocatoria de la Asamblea constituyente. Las leyes de desconexión no son susceptibles de control, suspensión o impugnación por parte de ningún otro poder, juzgado o tribunal»).Y el ATC 24/2017 de 14 de febrero anula la Resolución 306/XI de 6 de octubre de 2016 sobre la orientación política general del Gobierno (El Parlamento de Cataluña insta al Gobierno a poner en marcha la preparación de los procedimientos y reglamentos necesarios para hacer efectivo el referéndum (de autodeterminación)... El Parlamento de Cataluña creará una Comisión de expertos para el seguimiento del proceso de autodeterminación, integrada por personas del ámbito internacional que hayan conocido otros procesos similares y por juristas conocedores de esta materia... El Parlamento de Cataluña insta al Gobierno a definir, con el asesoramiento del Consejo Asesor del Proceso Constituyente, el programa y el calendario de desarrollo del proceso constituyente en el plazo de tres meses y bacerlo efectivo durante el primer semestre de 2017.)

Posteriormente y atendiendo a sus precedentes, la STC 90/2017 de 5 de julio declaró la inconstitucionalidad y nulidad de las partidas que los Presupuestos de la Generalitat 2017 destinan a procesos electorales y consultas populares en el caso que se dediquen a la financiación del proceso refrendario independentista (disposición adicional 40 de la ley presupuestaria): 


\begin{abstract}
"Por el contrario, sí son merecedoras de reproche de inconstitucionalidad al permitir financiar con cargo a sus dotaciones gastos que se pueden derivar de la organización y convocatoria del referéndum al que se refiere la disposición adicional 40. (...) La generalidad de las denominaciones y la inconcreción de los contenidos y destinos de dichas partidas, notas en las que los Letrados del Parlamento de Cataluña fundan su defensa, no privan de fundamento las dudas de constitucionalidad que suscitan, pues son precisamente esa generalidad e inconcreción, buscadas o no, las que las convierten en habilitadoras de créditos para dar cobertura financiera al referéndum. Por lo demás, la representación letrada del Gobierno y del Parlamento de Cataluña no ha acreditado que con las dotaciones incluidas en las partidas presupuestarias impugnadas, pese a la generalidad de su denominación e inconcreción de su contenido y destino, no puede financiarse aquel pretendido referéndum.»
\end{abstract}

Glosando esta Sentencia, el prof. García Fernández ${ }^{59}$ escribe: «A día de hoy (sin esperar al mes de septiembre) hay un acto jurídico que es la decisión del Gobierno catalán sobre el referéndum (decisión material aunque no esté formalizada) y actos no jurídicos de apoyo al acto jurídico ¿Debería intervenir el Gobierno español con un requerimiento al Tribunal Constitucional y a través del ministerio fiscal? A mi juicio, debería actuarse de inmediato porque hay un supuesto de hecho desencadenante (la decisión del Gobierno catalán) como por el mensaje de firmeza que se transmitiría (cuando la rebelión avanza, el Gobierno actúa). Es más, quizá una intervención en julio evitaría aplicar en septiembre el artículo 155 de la Constitución...».

Los hechos posteriores avalarían que para la restauración del orden constitucional en Cataluña fue preferible esperar a la llamada «Declaración Unilateral de Independencia»

\title{
6. LOS TRÁMITES FORMALES PREVIOS A LA COERCIÓN ESTATAL DEL ART. 155
}

El prof. García de Enterría ${ }^{60}$ remarca que el supuesto de hecho del art. 155 es precisamente la vulneración del principio de legalidad al que la Administración Pública está sujeta conforme al art. 103.1. Sobre este fundamento constitucional, se refiere a un requisito previo cual es que el Estado investigue y constate el incumplimiento por la Comunidad Autónoma de sus obligaciones constitucionales e incluso de actuaciones que atentasen gravemente el interés nacional. Parece imposible que algún atentado contra el interés nacional no supusiese al mismo tiempo un incumplimiento de obligaciones constitucionales. Nadie podría objetarlo. Más aún, parece razonable que el Estado objetivase estos incumplimientos mediante un proceso judi-

59 Javier García Fernández (2017): «Responsabilidades por el referéndum» en el diario madrileño El País, edición del 12 de julio de 2017.

60 Eduardo García de Enterría (1983): La ejecución autonómica de la legislación del Estado. Ed. Civitas. Madrid, pp. 163 a 189. 
cial que concluyese en el Tribunal Constitucional. Al ser éste el intérprete supremo de la Constitución (art. 1 L.O.T.C.), la desobediencia a sus sentencias objetivaría que se cumple el supuesto del incumplimiento de las obligaciones constitucionales que establece el art. 155. El procedimiento ante el Tribunal Constitucional para obtener esa sentencia podría ser indistintamente un recurso de inconstitucionalidad o un conflicto de competencias. Especialmente el prof. Albertí Rovira ${ }^{61}$ se ha mostrado contrario a esta opinión y sostiene que la decisión del Gobierno es autónoma de cualquier otro instrumento de control de constitucionalidad o de resolución de conflictos: «Dicha institución no se presenta como mecanismo que solo pueda ser puesto en marcha después de un intento de conciliación, o de un litigio judicial (...) la ejecución estatal forzosa se convertiría así meramente en un mecanismo de ejecución de sentencias, virtualidad a la que obviamente no puede reducirse la institución»

El requerimiento previo al Presidente de la Comunidad Autónoma no está sujeto ni a forma ni a plazo. Parece razonable que el requerimiento sea fehaciente, motivado, con determinación del incumplimiento denunciado y la rectificación pretendida. Del mismo modo y aunque no se establezca un plazo de respuesta, debe adecuarse al objeto del requerimiento y al tiempo necesario para la rectificación requerida. Hasta este punto llegó el litigio que en 1989 enfrentó al Gobierno central con el Gobierno de las Islas Canarias por la negativa de éste a aplicar la normativa europea sobre el desarme arancelario y la reducción en un $15 \%$ de los derechos de aduana sobre las mercancías comunitarias. El Consejo de Ministros remitió un requerimiento que, juntamente con el desplazamiento a Tenerife de Josep Borrell, secretario de Estado de Hacienda, resultó suficiente para que el Presidente autonómico Lorenzo Olarte certificase el acuerdo que dio fin al incidente.

En fin, la aprobación por la mayoría del Senado está sujeta a los trámites del procedimiento que fija el art. 189 del Reglamento del Senado (según la modificación de 16 de junio de 2000), a saber:

- Presentación por el Gobierno de una demanda al Presidente del Senado indicando contenido y alcance de las medidas

— Remisión a la Comisión General de las Comunidades Autónomas o a la Conjunta que se constituyese ad hoc que podría encomendar encuestas o estudios (art. 67)

- Advertencia a los senadores de designación autonómica de su derecho de asistencia e intervención (art. 56.bis.1) al igual que el Gobierno y los Consejos de gobierno autonómicos inclusive, claro está, el expresamente afectado (art. 56.bis.2)

- Audiencia al Presidente de la Comunidad Autónoma para alegaciones que podrá designar representante a estos efectos.

— Debate en Comisión de la propuesta razonada y enmendada.

${ }^{61}$ Enoch Albertí Rovira (1985): «La ejecución estatal forzosa» en E. Aja (dtor.): El sistema jurídico de las Comunidades Autónomas. Ed. Tecnos. Barcelona, p. 472. 
- Debate en el Pleno de las enmiendas y de la propuesta, con turnos a favor y en contra además de las intervenciones de los portavoces de los grupos parlamentarios

- Votación de la propuesta que ha de ser aprobada por la mayoría absoluta de los Senadores.

En un muy comentado artículo de prensa firmado por el prof. De Esteban sobre toda esta tramitación, llegaba a la siguiente conclusión: «Pues bien, lo que sucede es que nadie se ha apercibido de que el famoso artículo 155 - el cual debiera baber sido utilizado por el presidente del Gobierno - es en estos momentos inservible, inviable, no sirve para nada» ${ }^{62}$

\section{LOS SUPUESTOS DE HECHO DEL ART. 155.}

El art. 155 prevé dos supuestos de hecho diferentes aunque, a mi entender son coincidentes. El primero es el incumplimiento de obligaciones constitucionales o legales. El segundo es el de actuaciones que atenten al interés general.

Sobre el primero, el Tribunal Constitucional en su STC 215/2014 lo define como «incumplimiento manifiesto y contumaz, deliberado o negligente, de una de terminada Comunidad autónoma, que no ba adoptado, primero, por propia iniciativa, y luego, a instancia del Estado, las medidas oportunas para corregir la desviación en la que ha incurrido». Por su

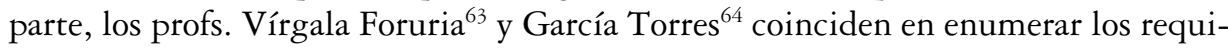
sitos exigibles:

- Un incumplimiento, positivo por acción o negativo por omisión, que afecte al sistema de distribución de competencias o al régimen de libertades.

- Gravedad y reiteración del incumplimiento sin ánimo de rectificarlo.

- El incumplimiento debe ser efectivo, en el bien entendido que una declaración parlamentaria susceptible de producir futuros efectos jurídicos responde a esta exigencia porque el Tribunal Constitucional ha resuelto que para que una resolución de una Comunidad Autónoma pueda ser objeto de impugnación a través del referido proceso constitucional es necesario que posea naturaleza jurídica; que sea, además, manifestación de la voluntad institucional de la Comunidad Autónoma, esto es, que proceda de órganos capaces de expresar la voluntad de ésta y no se presente como un acto de trámite en el procedimiento de que se trate; y, por último, que tenga, siquiera indiciariamente, capacidad para producir efectos jurídicos (STC 42/2014).

- El objeto de incumplimiento ha de ser la Constitución o las leyes y normas con rango legal, comunitarias, estatales o incluso, aunque resultase paradójico, autonómicas ${ }^{65}$.

\footnotetext{
${ }_{62}^{62}$ Jorge de Esteban (2017): «¿Se puede impedir el referéndum?» en El Mundo del 10 de julio de 2017.

${ }_{63}^{63}$ Eduardo Vírgala Foruria (2005): op. cit., pp. 85 a 99.

${ }^{64}$ Jesús García Torres (1984): op. cit., pp. 1254 a 1265.

${ }^{65}$ José M. ${ }^{a}$ Gil-Robles y Gil-Delgado (1999): op. cit., p. 509.
} 
- Imputabilidad objetiva a los órganos superiores de la Comunidad Autónoma, es decir el ejecutivo, el Presidente y su Gobierno; o el legislativo, el Parlamento autonómico. Tal vez no sea jurídicamente preciso que la imputabilidad sea culposa o dolosa pero solo mediando culpa o dolo es imaginable la implementación del art. 155.

El segundo de los supuestos de hecho es aún más inconcreto: grave atentado al interés general de España. ¿Está o no vinculado este supuesto con el anterior del incumplimiento constitucional?

El prof. Cruz Villalón ${ }^{66}$ defiende que son supuestos distintos, equipara el supuesto al propio de la dictadura constitucional, y escribe: «...aquí se convierte en una intervención que no necesita estar apoyada en ninguna infracción constitucional o legal, sino en razones de indole política libremente apreciadas por el Gobierno y el Senado».

En el extremo opuesto, el prof. Ballart Hernández ${ }^{67}$ sostiene que no hay diferencia entre ambos supuestos. Según este autor, la conjunción «o» que los separa en el texto significa «o sea». El inciso del grave atentado al interés general sería una especificación del único supuesto que sería el grave incumplimiento de las obligaciones constitucionales. El supuesto de hecho del art. 155 sería unívoco y se aplicaría cuando la Comunidad Autónoma no cumpliere las obligaciones que la Constitución u otras leyes le impongan «o sea» cuando actuare de forma que atente gravemente al interés general de España.

Por su parte, el prof. Vírgala Foruria ${ }^{68}$ introduce un matiz cualitativo y argumenta que el supuesto del grave atentado al interés general de España supondría una actuación no reconducible con la mera amenaza de la coerción estatal y se daría «... cuando el incumplimiento de las obligaciones se dirija frontalmente a la ruptura del marco constitucional en la distribución territorial del poder político, ignorando que la Comunidad Autónoma no es un ente soberano, sino sometido en su toma de decisiones a la Constitución de 1978 y a su legislación de desarrollo».

Coincidente con este parecer, el prof. García Torres ${ }^{69}$ especifica el incumplimiento de este supuesto y lo cifra en «...un incumplimiento, y de los más graves, de la obligación constitucional de fidelidad y solidaridad constitucionales, esto es, una infracción del análogo patrio de la Bundestreue germánica».

En mi opinión, el art. 155 contempla dos supuestos concurrentes pero decididamente distintos: uno es el incumplimiento de las obligaciones constitucionales; y el

${ }^{66}$ Pedro Cruz Villalón (1981): op. cit., p. 714

${ }^{67}$ Xavier Ballart Hernández (1987): Coerció estatal i autonomies. Estudi de l'article 155 de la Constitució de 1978. Escola d'Administració Pública de Catalunya. Barcelona, pp. 137 a 138: «Si això és cert, la conjunció» o «no denotaria alternativa sinó equivalencia i tindria el sentit d'» o sia «que tant el Diccionario de la Real Acadèmia de la Lengua Espanola com els de Casares i Fabra (aquest en català) contemplen. D'acord amb el que acabem de dir, perquè fos aplicable l'article 155, caldria que una CA no complís les obligacions que la Constitució o les altres lleis li imposen i que això suposés un atemptat greu contra l'interès general d'Espanya.»

68 Eduardo Vírgala Foruria (2005): op. cit., pp. 91 a 93.

69 Jesús García Torres (1984): op. cit., p. 1268. 
otro, el atentado al interés general. Es verdad que resulta difícil concebir un ejemplo en que una Comunidad Autónoma pudiese atentar gravemente al interés general de España sin que, al mismo tiempo, estuviese incumpliendo grave y reiteradamente sus obligaciones constitucionales. Sin embargo, el segundo supuesto refleja una cláusula de necesidad.

El primer supuesto del incumplimiento constitucional incide en el alcance jurídico del conflicto, mientras que el segundo del atentado al interés general transmite un especial alcance político. Así pues, parecería que para la constatación del supuesto del incumplimiento de las obligaciones jurídicas se estaría invocando el requisito de un previo proceso judicial que concluyese en el Tribunal Constitucional $^{70}$. Por el contrario, el segundo supuesto del atentado al interés general de España sería equiparable al incumplimiento evidente e infraganti. Para ejemplificar mi posición, el primer supuesto se cumpliría con la reiterada convocatoria de un plebiscito de autodeterminación tantas veces proscrito por el Tribunal Constitucional. El segundo, con motivo de la proclamación de la llamada «D.U.I.» (Declaració unilateral d'independencia).

En un arduo trabajo, insistente en utilizar la Doctrina alemana para explicar las

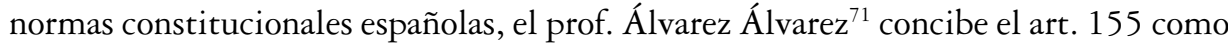
un precepto vinculado a la estructura del principio autonómico del art. 2; y describe su apartado 1 como una norma de sujeción y su apartado 2 como una norma de lealtad, al tiempo que limita el objeto de incumplimiento a las normas del bloque constitucional $\left(147.1,150,148.1 .22 .^{\circ}, 149.1 .29 .^{\circ}, 152.1\right)^{72}$. La coerción estatal del art. 155 sería la norma de cierre del sistema autonómico; y también la que regula una función no del Estado central sino del Estado «total» «llamada a definir el régimen jurídico al que todos los miembros del sistema descentralizado han de someterse imperativamente» y capaz de adoptar las medidas necesarias «allí donde la naturaleza de la función del TC como legislador negativo no puede llegar(...) permitiendo a los órganos previstos en el art. 155 CE «elevarse» — bajo determinadas condiciones - sobre las normas de la Constitución y del bloque constitucional...». Este sin duda valioso trabajo académico está tan alejado de la concepción sociológica de la norma constitucional que postulo que no soy capaz de imaginar a un Gobierno español que se atreviese a invocar su condición de órgano de un Estado total, amén de los principios de unidad y lealtad, para aplicar el art. 155 e imponer imperativamente a una o varias comunidades autónomas medidas necesarias inalcanzables para el Tribunal Constitucional.

70 Xavier Ballart Hernández (1987): op. cit., pp. 103 a 105.

71 Leonardo Álvarez Álvarez (2016): «La coerción estatal del artículo 155 CE en la estructura del Estado autonómico», en Teoría y Realidad Constitucional, n. ${ }^{\circ} 38$ UNED, Madrid, pp. 277 a 304.

72 Coincide con Xavier Ballart Hernández (1987): op. cit., pp. 125 a 126: «Cal que ara ens preguntem en quins casos l'incompliment de les lleis implicarà la vulneració dels principis constitucionals en els quals es concreta l'interès general. Creiem que això només succeirà quan s'incompleixin les lleis que componen el bloc de la constitucionalitat (art. 28 L.O.T.C.)» 


\section{EL PROCEDIMIENTO DE LA COERCIÓN ESTATAL}

Permítaseme una consideración previa. A mi entender, ni los políticos al reformar el Reglamento del Senado ni tampoco la Doctrina han entendido la excepcionalidad a la que responde la institución de la coerción estatal. Unos y otros compiten en introducir requisitos e interpretaciones en favor de la mora del proceso. Sin duda están guiados por un propósito garantista que limite la discrecionalidad del Gobierno. Ahora bien, el largo proceso que describiré resulta de todo punto incompatible con la característica de excepcionalidad que unánimemente se atribuye a la institución. Ello no obstante, es lo cierto que la declaración de octubre de 2017 evidenció una notable agilidad favorecida sin duda por el acuerdo entre el Partido Popular y el Partido Socialista.

El procedimiento para la coerción estatal está sujeto a los trámites del procedimiento que fija el art. 189 del Reglamento del Senado (según la modificación de 16 de junio de 2000). Se inicia con el requerimiento del Gobierno al Presidente de la Comunidad Autónoma.

Lógicamente, tal y como señala el prof. García de Enterría ${ }^{73}$, con anterioridad, el Estado habrá tenido que investigar y constatar el incumplimiento por la Comunidad Autónoma de sus obligaciones constitucionales e incluso de actuaciones que atentasen gravemente el interés nacional.

También el prof. Vírgala Foruria ${ }^{74}$ sugiere el dictamen del Consejo de Estado. De acuerdo con el art. 19 de la Ley orgánica 3/1980, para los expedientes urgentes, el dictamen deberá ser despachado por el Pleno en un máximo de 15 días, o en 10 días por la Comisión Permanente.

El requerimiento previo al Presidente de la Comunidad Autónoma no está sujeto ni a forma ni a plazo pero parece razonable que tenga que ser fehaciente, con especificación de las conductas denunciadas, la intimidación a corregirlas y la indicación del plazo para contestar. El prof. García Torres ${ }^{75}$ sugiere que por analogía del art. 63.4 L.O.T.C., el plazo para que el Presidente autonómico responda sea el de 1 mes. A mi entender sería mucho más eficaz aplicar el plazo de dos días hábiles que el art. 204 del Reglamento Notarial fija para la contestación a los requerimientos notariales.

Adviértase que el plazo para la contestación no puede equipararse al plazo de cumplimiento del requerimiento. La generalidad de los autores insiste en que el requerimiento del Gobierno debe dar un plazo razonable y proporcionado para el cumplimiento de las medidas requeridas. Son dos cuestiones diferentes. Una es la del plazo para contestar si se acepta o se niega el requerimiento. Nada más. Otra cuestión distinta es la del plazo para implementar las medidas que requiere el Gobierno. Para la primera, ese plazo de dos días hábiles es más que suficiente.

\footnotetext{
73 Eduardo García de Enterría (1983): op. cit., pp. 111 a 113.

${ }^{74}$ Eduardo Vírgala Foruria (2005): op. cit., p. 94.

75 Jesús García Torres (1984): op. cit. p. 1271.
} 
El Presidente autonómico tendría tres opciones: La primera sería aceptar los términos del requerimiento y corregir las actuaciones que se le denuncian. La segunda sería negar el requerimiento. Y la tercera sería no contestarlo en plazo ${ }^{76}$. El prof. García de Enterría plantea una cuarta cual es que el Presidente autonómico inste un conflicto de competencias ante el Tribunal Constitucional con súplica de suspensión del procedimiento hasta Sentencia (art. 61.3 L.O.T.C.) y escribe: «Son notorias las ventajas de que la Comunidad Autónoma discrepante con el requerimiento ponga en marcha esta vía. Con su apertura evitará normalmente la puesta en funcionamiento de las consecuencias que el artículo 155 babilita para el supuesto de una negativa pura y simple a seguir el requerimiento del Gobierno, las medidas ejecutivas y de sustitución que son siempre medidas críticas $y$ delicadas $\gg .{ }^{.7}$

La aceptación del requerimiento da fin al procedimiento obviando así la aprobación del Senado.

No es en absoluto descartable que el Presidente optase por el silencio y no contestase el requerimiento. Sería incluso previsible atendida la imputación de desobediencia por la que se le requiere. El problema radica en la determinación de los órganos desobedientes: si es el propio Presidente o su Consejo de Gobierno, carecería de justificación. Ahora bien, si el Gobierno requiriese por incumplimientos como los que los que describen en las resoluciones del Tribunal Constitucional sobre el procés en Cataluña, es asimismo previsible que el Presidente autonómico contestase con que no está entre sus facultades las de reprimir actuaciones de un Parlamento que representa la población de la Comunidad Autónoma y ejerce la potestad legislativa. Ello no obstante, parece indiscutible que la respuesta al requerimiento es potestativa del Presidente autonómico y que su silencio no suspende la tramitación del procedimiento.

Verificado el requerimiento sin una actuación correctora de la Comunidad autónoma, el Gobierno podrá presentar una demanda al Presidente del Senado, indicando contenido y alcance de las medidas.

La mesa del Senado remitirá la demanda a la Comisión General de las Comunidades Autónomas o a la Conjunta que se constituyese ad hoc que podría encomendar encuestas o estudios (art. 67). La Comisión advertirá a los senadores de designación autonómica de su derecho de asistencia e intervención (art. 56.bis.1) al igual que el Gobierno y los Consejos de gobierno autonómicos inclusive, claro está, el expresamente afectado (art. 56.bis.2).

A continuación, se da traslado del expediente para audiencia y alegaciones del Presidente de la Comunidad Autónoma.

Recogida la demanda del Gobierno y las alegaciones del Presidente autonómico requerido, se inicia el debate en Comisión de la propuesta razonada y enmendada. Una vez aprobada en Comisión, se remitirá al Pleno.

\footnotetext{
76 José M. ${ }^{a}$ Gil-Robles y Gil-Delgado (1999): op. cit., pp. 511 a 513.

77 Eduardo García de Enterría (1983): op. cit., p. 179.
} 
En el Pleno se debaten las enmiendas ${ }^{78}$ y la propuesta, con turnos a favor y en contra además de las intervenciones de los portavoces de los grupos parlamentarios. El prof. Vírgala Foruria ${ }^{79}$ echa en falta que también en Pleno pudiese intervenir el Presidente autonómico requerido.

El procedimiento parlamentario concluye con la votación de la propuesta que ha de ser aprobada por la mayoría absoluta de los Senadores.

Una vez aprobada la propuesta, el Gobierno está facultado para ejecutar las medidas. Coincido con la opinión de aquellos autores ${ }^{80}$ según la cual, atendidas las circunstancias y la rectificación de la Comunidad Autónoma, el Senado habría de poder revocar parcial o totalmente las medidas sin que para ello fuese necesaria la previa solicitud del Gobierno que reclama el prof. Calafell Ferrá ${ }^{81}$. Es verdad que no existe una previsión legal a este respecto y sin embargo entiendo que procede la aplicación del principio qui potest plus, potest minus. De la misma manera que el Senado pudo aprobar la autorización al Gobierno ha de poder revocarla con la misma mayoría.

La aprobación por el Senado es un acto con fuerza de ley (art. 27.2.b L.O.T.C.) «en la medida en que viene a excepcionar, modificar o condicionar durante ese periodo la aplicabilidad de determinadas normas entre las que pueden quedar afectadas leyes, normas o disposiciones con rango de ley, cuya aplicación puede suspender o desplazar» (STC 83/206). Y, por consiguiente, tanto en su totalidad como por lo que se refiere a alguna de sus medidas, es susceptible de recurso ante el Tribunal Constitucional, bien por la vía del recurso de inconstitucionalidad o bien por la vía del conflicto de competencias ${ }^{82}$. Este recurso podría plantear un problema de legitimación activa en el supuesto de que, entre las medidas aprobadas, se incluyese la suspensión del Consejo de Gobierno o el Parlamento de la Comunidad Autónoma afectada incluso para instar procedimientos ante el Tribunal Constitucional.

Si la suspensión o el cese afectasen al Consejo de Gobierno autónomo, ya no podría instar ni un recurso de inconstitucionalidad ni un conflicto de competencias. Tanto en el art. 32.2 L.O.T.C. sobre el recurso de inconstitucionalidad como en los arts.60 y 62 L.O.T.C. sobre los conflictos de competencia entre el Estado y las Comunidades Autónomas, la legitimación corresponde a los órganos colegiados ejecutivos de las Comunidades Autónomas y, ni aun entendiendo que el Consejo cesado está en funciones, cabría incluir semejante decisión dentro de la facultad del despacho ordinario de los asuntos públicos (p. e. art. 27 de la Ley 13/2008 del Parlamento de Cataluña, de la

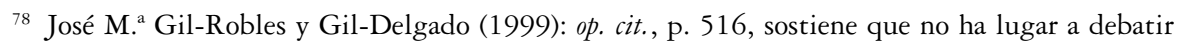
enmiendas en el Pleno.

79 Eduardo Vírgala Foruria (2005): op. cit., p. 97.

80 José M. ${ }^{a}$ Gil-Robles y Gil-Delgado (1999): op. cit., p. 517. Vicente J. Calafell Ferrá (2000): «La compulsión o coerción estatal (estudio del artículo 155 d la Constitución española)» en Revista de Derecho Político n. ${ }^{\text {48-49. Madrid, p. } 125 .}$

81 Vicente J. Calafell Ferrá (2000): op. cit., p. 125.

82 José M. ${ }^{a}$ Gil-Robles y Gil-Delgado (1999): op. cit., p. 517 
Presidencia de la Generalitat y del Gobierno). Tanto más si la medida aprobada por el Senado fuese la sustitución del Consejo de Gobierno autónomo por una autoridad central.

Quedarían exentas del control del Tribunal las decisiones que se fundamentasen en una valoración de oportunidad política aunque la Jurisprudencia constitucional sobre el supuesto de hecho del art. 86 («extraordinaria y urgente necesidad») presenta innumerables precedentes de complejas discusiones sobre esta cuestión.

\section{LAS MEDIDAS DEL ART. 155.}

El art. 155 no indica cuáles habrían de ser las medidas propias de la coerción estatal. Antes al contrario, se limita a establecer un criterio indeterminado y establece que serán las «necesarias» para obligar al cumplimiento de las obligaciones o para la protección del interés general. Correspondería al Gobierno y al Senado determinar qué es necesario con un margen de discrecionalidad que está limitado precisamente por lo que no sea necesario ${ }^{83}$.

Haciéndose eco de las propuestas de la Doctrina, el prof. Vírgala Foruria ${ }^{84}$ enumera los principios a que deberían atenerse esas medidas, a saber: Gradualidad, necesidad, proporcionalidad, adecuación, transitoriedad con fijación de plazo, concreción, mínima intervención de los derechos autonómicos. Y el prof. García de Enterría ${ }^{85}$ extrapola la regla procesal de las costas y añade la imputación a la Administración autonómica de los costos de la intervención correctora.

En mi opinión, además de los principios enumerados, dos son los límites exigibles. De una parte, que las medidas no conlleven la suspensión indefinida de la autonomía al modo de la direct rule británica que se aplicó reiteradamente en el Ulster desde 1998 hasta el 2007. Y en segundo lugar, que tampoco comporten una alteración irreversible del sistema de distribución de competencias establecido en el bloque de constitucionalidad, la Constitución y el Estatuto de Autonomía.

Bajo estos principios, el listado de las medidas podría ser el siguiente:

— Dictado de instrucciones dirigidas a cualesquiera autoridades autonómicas, superiores o inferiores.

— Privación de efectos jurídicos y de ejecutividad a los actos de los órganos de la Administración autonómica desautorizados.

— Restauración de efectos inaplicados por la inactividad autonómica.

- Suspensión de cesiones y transferencias tributarias y financieras.

${ }^{83}$ Fernando Simón Yarza (2017): «Sobre el artículo 155 de la Constitución» en el diario El País, edición del 23 de octubre de 2017.

${ }^{84}$ Eduardo Vírgala Foruria (2005): op. cit. pp. 99 a 105.

${ }^{85}$ Eduardo García de Enterría (1983): op. cit., p. 186. 
- Sustitución o subrogación de los órganos superiores de la Administración autonómica por otros de la Administración central (STC 2015/2014, FJ 8)

— La declaración de indisponibilidad de los fondos económicos de la comunidad autónoma o la constitución de un depósito obligatorio (art. 26 Ley orgánica 2/2012 de estabilidad presupuestaria y sostenibilidad financiera).

Dos medidas posibles han sido las que más literatura dogmática han producido: La disolución de los entes autonómicos y el uso de las fuerzas de seguridad y militares.

La Doctrina es unánime en que no cabe la supresión de la Autonomía al modo de la direct rule en el Ulster. Se trataría de una decisión manifiestamente inconstitucional porque vulneraría el derecho a la autonomía de regiones y nacionalidades previsto en el art. 2 de la Constitución española. No parece discutible que la coerción estatal del art. 155 tiene un límite en la propia Constitución. Sobre esta cuestión, la prof. Barceló Serramalera ${ }^{86}$ escribe: «Suspender la autonomía significaría dejar sin efecto el artículo 2 de la CE, que reconoce el derecho a la autonomía de nacionalidades y regiones (...) la suspensión de la autonomía supone indefectiblemente la suspensión del estatuto. Y la suspensión del Estatuto constituye una afectación directa de su vigencia y eficacia como norma jurídica».

Mucha menos unanimidad genera la posibilidad de disolver los órganos autonómicos.

Las opiniones no son pacíficas. Eduardo García de Enterría ${ }^{87}$ sostiene que la medida de la sustitución está especificada en el art. 155.2 que otorgaría al Gobierno un poder general de mando directo sobre las autoridades autonómicas. El prof. Albertí Rovira $^{88}$ defiende que solo cabe la sustitución para la realización de aquellas actividades cuyo ejercicio esté afectado por el art. 155. Por el contrario, los profs. Cruz Villalón ${ }^{89}$, Ortega Gutiérrez ${ }^{90}$ y Carreras Serra ${ }^{91}$ sostienen que cabe tanto su sustitución como su disolución, incluso del Parlamento con convocatoria de nuevas elecciones. Más contundente, el profesor de la Universidad Carlos III, Miguel Satrústegui ${ }^{92}$ enumera tres baterías de medidas: la disolución del Parlamento autonómico con convocatoria de nuevas elecciones; la destitución del Presidente de la Comunidad autónoma; y la asunción por el Gobierno central del ejercicio de las competencias en materia de seguridad pública.

\footnotetext{
${ }^{86}$ Mercé Barceló Serramalera (2013): «Un error interesado» en El Periódico, 28 de noviembre de 2013.

87 Eduardo García de Enterría (1983): op. cit. pp. 186 a 187.

88 Enoch Albertí Rovira (1985): op. cit., pp. 471 a 476.

89 Pedro Cruz Villalón (1984): op. cit. p. 60.

90 David Ortega Gutiérrez (2017): «Ante un Parlamento «ilegítimo», elecciones ya», en El Mundo, 20 de octubre de 2017.

91 Francesc de Carreras Serra (2017): «Necesarias y proporcionadas» en El País, 24 de octubre de 2017.

92 Manuel Satrústegui Gil-Delgado (2017): «Molt Honorable President» en El País, 16 de octubre de 2017 .
} 
El prof. Arbós Marín ${ }^{93}$ mantiene una tesis diferente y defiende que las medidas que el Gobierno puede «adoptar» según el art. 155.1 solo se pueden «ejecutar» mediante el mecanismo que establece el art. 155.2, es decir dando instrucciones a las autoridades de las Comunidades Autónomas sin que quepa ni la disolución del Parlament ni la sustitución de una autoridad autonómica por otra designada por el Gobierno central. En todo caso, tal y como destaca el prof. Álvarez Álvarez ${ }^{94}$, para activar la sustitución ex art. 155 sería necesario una desobediencia previa de la Comunidad Autónoma a una resolución del Tribunal Constitucional ex art. 92.4.c L.O.T.C.

A propósito del conflicto en Cataluña y en gran medida coincidentes con la tesis del prof. Arbós, los letrados del Parlament de Cataluña Imma Folchi, Esther Andreu, Francisco Paz, Joan Ridao y Pedro Sol firmaron un Informe del 18 de octubre de 2017 en el que sostienen la dudosa constitucionalidad de las medidas propuestas por el Gobierno central la fecha de 21 de octubre de 2017, más concretamente la destitución del Presidente Puigdemont y los consejeros de su Gobierno. Argumentan que es una medida que atenta al principio de autogobierno de las Comunidades Autónomas que establece el art. 143 de la Constitución. Añaden que el cese del Presidente de la Comunidad vulneraría no solo los rasgos característicos del sistema parlamentarista sino además el art. 152.1 cuando establece que corresponde al Presidente autonómico la dirección del Consejo de Gobierno y la suprema representación del Estado en la Comunidad: «No se puede transmutar una facultad estatutaria del President de la Generalitat en un deber impuesto a extramuros del Estatuto. Lo contrario sería tanto como operar una modificación del Estatuto al margen de los mecanismos previstos para su reforma, por la vía de una mera instrucción». Plantean por otra parte un problema de jerarquía normativa porque el Estatuto tiene rango de ley orgánica (art. 81.1) e integra el bloque de constitucionalidad, de modo que, en su opinión, no podría ser derogado por un Real Decreto del Gobierno.

No recuerdo tantas opiniones de mis colegas en los medios de comunicación como las que ha generado este conflicto. Sus aportaciones son sin duda importantes pero la verdaderamente decisiva será la del Tribunal Constitucional con motivo del recurso de inconstitucionalidad instado por el Grupo Parlamentario de Unidos-Podemos que salva así la inadmisión a trámite del recurso de inconstitucionalidad instado por el Consejo de Gobierno de la Generalitat (Auto 142/2017 de 31 de octubre $^{95}$. No creo que el apartado 2 del art. 155 constriña lo que se establece en el apartado $1 \mathrm{y}$, por consiguiente, la facultad de dar instrucciones a las autoridades autonómicas no es la única sino una de las muchas posibles medidas necesarias para

93 Xavier Arbós Marín (2015): «Los límites del artículo 155» en El Periódico, 10 de noviembre de 2015.

${ }_{94}$ Leonardo Álvarez Álvarez (2016): op. cit., pp 298 a 299.

95 El T.E.D.H. con fecha 24 de octubre de 2017 dictó una Resolución acordando inadmitir a trámite una demanda firmada por David Bondía, Presidente del Institut dels Drets Humans, de Catalunya en la que se suplicaba la suspensión cautelar de la aplicación del art. 155. 
forzar al cumplimiento de las obligaciones constitucionales desobedecidas. Por otra parte, a mi entender, la facultad del Gobierno y del Senado para determinar las medidas necesarias tiene un amplio ámbito de discrecionalidad. Ciertamente que el límite es el de que las medidas adoptadas no fuesen necesarias o manifiestamente inconstitucionales. La cuestión estriba en que la decisión para determinar cuáles son necesarias y cuáles innecesarias corresponde al Gobierno central. En la práctica este límite es meramente formal y se traduce en la obligación de fundamentar suficientemente el listado de medidas.

También se ha planteado en la Doctrina ${ }^{96}$ si entre las medidas del art. 155 se incluye el uso de la fuerzas de orden público e incluso de las Fuerzas Armadas. Me parece que no ha lugar a esta discusión. El uso de estas fuerzas está previsto para otros supuestos previstos en la Ley orgánica 4/2015 de seguridad ciudadana, en la Ley 5/2015 de Defensa nacional o para los estados excepcionales del art. 116 desarrollados en la Ley orgánica 4/1981.

En fin, implementadas éstas o cualesquiera otras medidas, permanecerá abierta la vía del recurso administrativo, contencioso administrativo o, en su caso, del recurso de amparo ante el Tribunal Constitucional. Es verdad que la Sala de lo Contencioso Administrativo del Tribunal Supremo denegó la petición cautelarísima planteada por la Generalitat de Catalunya y el Govern de suspender el acuerdo del Consejo de Ministros de 21 de octubre de 2017; y que también el Tribunal Constitucional inadmitió sendos recursos de amparo del abogado Oriol Casals y de los senadores de PdCat. Todas estas resoluciones coincidieron en que hasta tanto no hubiesen sido acordadas por el Senado, las medidas propuestas por el Gobierno no habían sido aún adoptadas y eran susceptibles de modificación o rechazo en el Senado.

\section{LA EXCEPCIONALIDAD POLÍTICA Y JURÍDICA DEL ART. 155.}

Tal y como está la coerción estatal regulada en el art. 155 plantea un problema político complejo. Como todas las normas constitucionales, es una norma con un marcado contenido político. La particularidad que plantea es que su contorno de incerteza es mayor que su núcleo de certeza. La Resolución del Senado del 27 de octubre de 2017 constituye el primer precedente de la aplicación del precepto. Su alcance fue particularmente contundente: cesó a los cargos del Govern, disolvió el Parlament y convocó nuevas elecciones autonómicas. Tras algunas incertidumbres iniciales, finalmente el Tribunal Constitucional se pronunciará al respecto porque 50 diputados del Grupo Parlamentario de Unidos-Podemos han instado un recurso de inconstitucionalidad.

96 Entrevistas a Roberto Blanco Valdés y Eduardo Vírgala Foruria en el diario madrileño El País, edición del 19 de julio de 2017. 
Alguna Doctrina constitucionalista española ${ }^{97}$ ha porfiado en establecer similitudes con la coerción federal del art. 37 de la Ley Fundamental de Bonn. Es un esfuerzo inútil. Más allá de las semejanzas literales, subyace una diferencia esencial, radical y fundamental. El Bundesrat y el Senado son dos cámaras altas perfectamente distintas. El Bundesrat es una cámara de representación de los Estados federados, mientras que el Senado es una cámara alta de doble lectura cuyos integrantes directos son cooptados por las comisiones ejecutivas de sus partidos para participar en unas elecciones convocadas por circunscripciones provinciales. Así pues, tal y como se regula la coerción estatal en Alemania, la resolución de imponer medidas coercitivas a un Estado incumplidor viene aprobada por el resto de los demás Estados federados. Solo esta circunstancia dota a la institución de la coerción federal de solidez política y de certeza jurídica.

La decisión de sustituir a las autoridades de una Comunidad autónoma por otras del Estado central o de intervenir las finanzas autonómicas es una determinación traumática de gravísimo calado político. En los sistemas presidencialistas, el Presidente disfruta de una legitimidad directa otorgada por el pueblo. Sin embargo, en los sistemas parlamentaristas, el Presidente del Gobierno es elegido por el Parlamento de modo que su legitimidad es indirecta de segundo grado. Este es el motivo por el que el que en las constituciones alemana o española, la coerción no se atribuye al Presidente del Gobierno por sí solo. Antes al contrario, precisa de la aprobación de un órgano legitimado por el pueblo y en primer grado, es decir el Parlamento. Se trata de un requisito capital. A diferencia del Bundesrat, en el Senado español no están representadas las autonomías. De haber sido como en Alemania, la aplicación de la coerción del art. 155 a una comunidad autónoma vendría aprobada por el resto de las comunidades autónomas Serían todas las demás las que le reprocharían su falta de solidaridad y lealtad. Pero no es así como se reguló el Senado en la Constitución de 1978.

A mi entender, la coerción estatal regulada en el art. 155 queda en manos del Presidente del Gobierno y de los grupos políticos del Senado que la voten a favor. Es, pues, una resolución alejada de la legitimidad política y jurídica de la intervención federal del art. 37 de la Ley Federal de Bonn. No se discute que el art. 155 regule un procedimiento con irreprochable legitimación constitucional. Lo que discuto es su similitud con la intervención federal alemana que además disfruta del plus de legitimidad que le confiere la decisión de un Bundesrat configurado como auténtica cámara de representación de los Länder.

Debo, sin embargo, reconocer que alguna de la mejor Doctrina española sostiene la tesis contraria. Así se constata de las encuestas publicadas por El País ${ }^{98}$ y La Van-

97 V. Antonio Arroyo Gil (2015): «Unidad, lealtad, y coerción federal (o estatal) en Alemania y España» en Revista Jurídica de la Universidad Autónoma de Madrid, n. ${ }^{\circ}$ 31. Madrid, pp. 51 a 70. Y Leonardo Álvarez Álvarez (2008): op. cit., pp. 493 a 524.

98 Diario El País, edición de 8 de julio de 2017. 
guardia ${ }^{99}$. Roberto Blanco Valdés declaró que «Creo que es obvio que hay que aplicarlo antes de que se celebre el referéndum y se proclame la independencia. Tras la independencia, el 155 es un pellizco de monja. Para la paz civil en España y Cataluña es mejor evitar el referéndum aplicando el 155 que permitir que se celebre por no aplicarlo». Agustín Ruiz Robledo ${ }^{100}$ escribió un artículo de prensa afirmando que «Si, por el contrario, la Generalitat avanzara en su desafío y convocara por su cuenta y riesgo una "consulta», la Constitución también of rece herramientas para impedirlo: impugnación de la convocatoria ante el Constitucional, lo que automáticamente supone su suspensión y, si la Generalitat se empecinara en celebrarlo, uso de las medidas coactivas que permite el artículo 155 de la Constitución...». Antonio Torres del Moral afirmó que «en mi opinión ya se han dado motivos para haberlo empleado; pero el principio de intervención mínima ha aconsejado, razonablemente, a los políticos no utilizarlo todavía». Sobre las medidas posibles, Javier Corcuera Atienza matiza: "Las medidas pueden significar meter en la cárcel a todo el mundo o solo anular jurídicamente los actos». Javier García Roca concluye «El Gobierno no tiene más límites que el principio de proporcionalidad y la autorización del Senado. Podría aplicarse en el caso de la moción independentista porque se sitúa fuera de la democracia porque no bay legitimidad democrática fuera de la legalidad».

Ante la excepcionalidad del art. 155, cabe preguntarse si existen otros mecanismos jurídicos que sean igualmente eficaces y de más fácil aplicación. Claramente el primer mecanismo alternativo es el de los recursos ante el Tribunal Constitucional para impugnar la constitucionalidad de las resoluciones o las declaraciones del Gobierno y el Parlamento autonómicos incumplidores o rebeldes. El Presidente del Gobierno central dispone de los mecanismos de los arts. 162.1 (recurso de inconstitucionalidad), 161.1.c (conflictos de competencia) y, muy especialmente, la suspensión del 161.2 («El Gobierno podrá impugnar ante el Tribunal Constitucional las disposiciones y resoluciones y disposiciones adoptadas por los órganos de las Comunidades Autónomas. La impugnación producirá la suspensión de la disposición o resolución recurrida, pero el Tribunal, en su caso, deberá ratificarla o levantarla en un plazo no superior a cinco meses»).

Se trata de un instrumento de enorme eficacia. En todos los tribunales constitucionales o supremos con competencias constitucionales, el Ejecutivo participa del nombramiento de los miembros del Tribunal. También en el caso español conforme se regula en el art. 159 de la Constitución. Entre las razones que llevaron a que Barak Obama nombrase a la Juez Sonia Sotomayor está su afinidad ideológica, al igual que en el caso del nombramiento de Nail Gorsuch por el presidente Donald Trump.

Por supuesto que la eficacia del recurso ante el Tribunal Constitucional depende de la ejecutividad de sus resoluciones frente a todos los poderes públicos (arts. 164 CE, 87 LOTC, 5.1 LOPJ), incluidas las fuerzas de seguridad (arts. 5 Ley orgánica de Fuerzas y cuerpos de seguridad, 4 Ley orgánica 4/2015 de seguridad ciudadana).

99 Diario barcelonés La Vanguardia, edición de 28 de octubre de 2015.

100 Agustín Ruiz Robledo (2014): «Lifting a la Constitución» en El País, edición del 16 de enero de 2014 . 
En su Declaración 1/XI de 9 de noviembre de 2015 el Parlamento de Cataluña anuncia que desobedecerá las decisiones del Estado español en general y en particular las del Tribunal Constitucional al que niega legitimidad. La STC 259/2015 declaró la inconstitucionalidad de aquella Declaración. Ello no obstante, el Parlamento de Cataluña aprobó otras tres resoluciones n. ${ }^{\circ}$ 5/2016 por la que se crea una comisión parlamentaria para el estudio del proceso constituyente; 263/2016 que acuerda el inicio de un proceso constituyente; y 306/2016 en la que crea una Comisión de expertos para el seguimiento del proceso de autodeterminación y un Consejo Asesor del Proceso Constituyente para definir el programa y el calendario de desarrollo. En aplicación de las nuevas facultades de ejecución de los arts. 87 y 92 L.O.T.C. (según la modificación introducida mediante Ley orgánica 15/2015 de 16 de octubre), el Tribunal Constitucional anuló las tres Resoluciones en otros tantos Autos 141/2016, 170/2016 y 24/2017. En este último se lee:

"Tal cuestión deberemos resolverla aplicando los criterios sentados por la doctrina constitucional en materia de incidentes de ejecución (arts. 87.1 y 92 LOTC), pues corresponde al Tribunal Constitucional velar por el cumplimiento efectivo de sus sentencias y resoluciones. $\mathrm{Ha}$ de resolver las incidencias de ejecución de las mismas, adoptando cuantas medidas considere necesarias para preservar su jurisdicción, incluyendo la declaración de nulidad de aquellos actos $y$ resoluciones que la contravengan o menoscaben, como expresamente establecen los arts. 4.1 y 92.1 LOTC, así como, en su caso, de la aplicación de otras medidas encaminadas a asegurar el debido cumplimiento de las sentencias y resoluciones de este Tribunal, al que están obligados todos los poderes públicos (art. 87.1 LOTC), incluidas las Cámaras legislativas...»

Esta reforma del art. 92 de la Ley orgánica del Tribunal Constitucional le atribuye expresas facultades de ejecución para lo que podrá recabar el auxilio de cualquiera de las administraciones y poderes públicos. Pero es en el apartado 4 de este artículo en el que se regula una auténtica y eficaz coerción estatal porque a nadie se le escapa que, más allá de que no se mencione expresamente, la normativa está dirigida a las autoridades de las comunidades autónomas.

Este apartado establece que el incumplimiento de una resolución del Tribunal Constitucional le facultará para adoptar una cualquiera de estas cuatro «medidas»:

a) Imponer multa coercitiva de tres mil a treinta mil euros a las autoridades, empleados públicos o particulares que incumplieren las resoluciones del Tribunal, pudiendo reiterar la multa hasta el cumplimiento integro de lo mandado.

b) Acordar la suspensión en sus funciones de las autoridades o empleados públicos de la Administración responsable del incumplimiento, durante el tiempo preciso para asegurar la observancia de los pronunciamientos del Tribunal.

c) La ejecución sustitutoria de las resoluciones recaídas en los procesos constitucionales. En este caso, el Tribunal podrá requerir la colaboración del Gobierno de la Nación a fin de que, en los términos fijados por el Tribunal, adopte las medidas necesarias para asegurar el cumplimiento de las resoluciones.

d) Deducir el oportuno testimonio de particulares para exigir la responsabilidad penal que pudiera corresponder. 
El apartado 5 incluye una quinta medida aún más excepcional, inaudita parte y sumaria:

"5. Si se tratara de la ejecución de las resoluciones que acuerden la suspensión de las disposiciones, actos o actuaciones impugnadas y concurrieran circunstancias de especial transcendencia constitucional, el Tribunal, de oficio o a instancia del Gobierno, adoptará las medidas necesarias para asegurar su debido cumplimiento sin oír a las partes. En la misma resolución dará audiencia a las partes y al Ministerio Fiscal por plazo común de tres días, tras el cual el Tribunal dictará resolución levantando, confirmando o modificando las medidas previamente adoptadas.»

Compárese este procedimiento con el de los arts. 155 de la Constitución y 189 del Reglamento del Senado. En ambos tiene el Gobierno legitimación activa para formular la demanda. Ambos concluyen con una sentencia del Tribunal Constitucional, tanto el del art. 92 L.O.T.C. porque así lo indica su apartado 5, como el del art. 155 porque la decisión del Senado es recurrible ante el Tribunal Constitucional por el Presidente o el Parlamento autonómico afectado. Ambos coinciden en que su objeto abarca a todas a las «medidas necesarias», es decir aquellas que discrecionalmente el Gobierno suplique y Tribunal Constitucional finalmente decida.

Esto supuesto, la opción por el farragoso procedimiento del art. 155 de iniciativa gubernamental presupone una situación extraordinariamente grave y apremiante. Solo así se entiende el relegamiento del procedimiento del art. 92 L.O.T.C., sumario, inaudita parte, de iniciativa jurisdiccional e irrecurrible.

Entre las medidas que el Gobierno puede utilizar sin acogerse al art. 155 se hallan otras más específicas y, entre ellas, las que se refieren a las finanzas de la Comunidad Autónoma afectada. Los instrumentos podrían ser dos. El primer es el F.L.A. (Fondo de Liquidez Autonómico) que el Gobierno central controla a través del Instituto de Crédito Oficial que depende del Ministerio de Economía. Se trata de una línea de crédito para que las comunidades autónomas atiendan sus deudas.

Por otra parte, la Ley orgánica de Financiación de las Comunidades Autónomas regula la cesión de tributos estatales que recauda el Estado y solo posteriormente se liquidan a la Comunidad Autónoma (arts. 10, 11 y 12); el Fondo de suficiencia global (art. 13); la autorización del Estado para emitir títulos de deuda (art. 14); y el Fondo de Compensación (art. 16). Y, en fin, la Ley orgánica 2/2012 de estabilidad presupuestaria y sostenibilidad financiera faculta al Gobierno para adoptar medidas coercitivas para la retención de los créditos de la autonomía incumplidora (art. 25).

Son, todos ellos, fondos económicos cuyo desembolso por el Gobierno central podría quedar condicionado a que las autoridades de la Comunidad Autónoma no pudiesen utilizar estos instrumentos para la actividad litigiosa.

Aún más específica sería la medida que resulta del precedente de la Sentencia del Tribunal de Justicia Superior de Cataluña de fecha 13 de marzo de 2017 dictada en el procedimiento $1 / 2016$, abierto con motivo de la celebración de la llamada 
consulta popular no refrendaria del 9N, y que concluyó con una fallo que condenó a Artur Mas, ex Presidente de la Generalitat, Joana Ortega, exvicepresidente e Irene Rigau, exconsellera de Educación por un delito de desobediencia a las penas de multa e inhabilitación para el ejercicio de cargos públicos. En la Sentencia se consideraron hechos probados y punibles los de desobediencia de la Providencia del Tribunal Constitucional de 4 de noviembre de 2014 en términos tan claros como imperativos: se acuerda suspender los actos impugnados..., así como las restantes actuaciones de preparación de dicha consulta o vinculadas a ella»; al tiempo que se identifican los «actos impugnados»: «las actuaciones de la Generalitat de Cataluña relativas a la convocatoria a los catalanes, las catalanas y las personas residentes en Cataluña para que manifiesten su opinión sobre el futuro político de Cataluña el día 9 de noviembre ( $y$ en los días sucesivos en los términos de la convocatoria), mediante un denominado «proceso de participación ciudadana».

Este precedente consta mencionado en los dos Autos dictados el 2 de noviembre de 2017 por la Juez Lamela del Juzgado Central de Instrucción n. ${ }^{\circ} 3$ de la Audiencia Nacional en las Diligencias Previas n. ${ }^{\circ}$ 82/2017. Por los delitos de rebelión, sedición y malversación de fondos públicos, acordó la prisión provisional sin fianza de los que fueron miembros del Consell de Govern de la Generalitat, Sres. Oriol Junqueras, Jordi Turull, Raúl Romeva, Josep Rull, Dolors Bassa, Meritxell Borrás, Joaquim Forn y Carles Mundó a quienes se imputa su participación en la convocatoria del referéndum del 1 de octubre, la posterior declaración de independencia del 27 de octubre de 2017 además de la posterior aprobación de normas y resoluciones dirigidas a dotar de aparente cobertura normativa al proceso de secesión. Todas estas actuaciones supuestamente rebeldes fueron efectivamente implementadas aún a pesar de las sucesivas declaraciones de inconstitucionalidad dictadas por el Tribunal Constitucional que fueron repetidamente ignoradas.

Resulta especialmente esclarecedora la relación de hechos que la Juez considera enjuiciables: Los partidos coaligados en Junts pel Sí y la C.U.P., además de las asociaciones Assemblea Nacional Catalana y Omnium Cultural, elaboraron el documento estratégico EnfoCATs sobre la convocatoria de un referéndum de autodeterminación y la posterior declaración unilateral de independencia (D.U.I) para crear la República catalana y abrir un debate constituyente. El 9 de noviembre de 2015 el Parlamento aprobó la Resolución 1/XI sobre el inicio del procés y la expresa manifestación de desobediencia a las resoluciones del Tribunal Constitucional. Desde enero de 2016 hasta septiembre de 2017, se dictaron varias resoluciones autonómicas encaminadas a la celebración del referéndum secesionista y su dotación presupuestaria que fueron sucesivamente declaradas inconstitucionales. Finalmente, el 1 de octubre, el Govern y las asociaciones soberanistas convocaron a un alto número de ciudadanos a una votación favorecida por la actitud pasiva de los Mossos d'Esquadra. Y el 27 de octubre el Pleno del Parlament votó y aprobó la declaración unilateral de independencia. 
Apenas un mes después y mediante Resolución de 31 de noviembre de 2017, la Sala Segunda del Tribunal Supremo declaró su competencia para conocer de todas las causas referidas a los hechos enjuiciados, incluidas las Diligencias Previas n. ${ }^{\circ}$ 82/2017 de la Audiencia Nacional, que se acumularon en la Causa especial n. ${ }^{\circ} 20907 / 2017$. El Auto de 4 de diciembre de 2017, dictado por el instructor Juez Llarena acordó señalar libertad bajo fianza a los Sres. Turull, Romeva, Rull, Bassa, Borrás y Mundó. El mantenimiento de la prisión para Oriol Junqueras y Joaquim Forn aparece fundamentado en el riesgo de reiteración delictiva del art. 503.2 LECr. Juntamente con Jordi Sánchez y Jordi Cuixart, máximos dirigentes de las asociaciones Assemblea Nacional Catalana y Ominium Cultural, integraban el Comité estratégico de procés descrito en el documento estratégico EnfoCATs. Y ambos habrían participado en la convocatoria del asedio que decenas de miles de manifestantes bicieron a la comisión judicial que ejecutó el registro de las instalaciones de la Consejería de Economía.

Siguiendo estos precedentes y para hechos similares que se produjesen en el futuro, el Gobierno podría dar cuenta a la Fiscalía General del Estado de una supuesta comisión de los delitos de desobediencia (Código Penal, arts. 327.b y 556) malversación de fondos públicos (Código Penal arts. 432 a 435), resistencia y desobediencia a la autoridad (Código Penal, art. 550), usurpación de funciones (Código Penal, arts. 506 y 508), prevaricación ( Código Penal, arts. 404 a 406), sedición (Código Penal, arts. 544 a 549) y rebelión (Código Penal, arts. 472 a 484). La calificación conllevaría, entre otras, la pena de inhabilitación, multa y, en su caso, también responsabilidad civil de la que el condenado debería responder con su patrimonio.

La tramitación de cualquier nuevo proyecto de ley secesionista implica su necesaria inclusión en el orden del día de una sesión parlamentaria y para ello es precisa la votación de la Mesa del Parlamento. La otra alternativa sería su aprobación por decreto ley aprobado por el Consejo del Gobierno catalán. En ambos casos, los miembros de la Mesa que firmasen esa orden del día o los del Gobierno que suscribiesen el decreto ley correrían un inminente riesgo de procesamiento por las mismas causas que las de la Causa especial 20907/2017.

En fin, restan algunos otros instrumentos legales de enorme contundencia: la Ley orgánica 4/2015 de seguridad ciudadana, la Ley 5/2015 de Defensa nacional. Y, por último, el art. 116.3 de la Constitución regula la declaración del estado de excepción por causa de grave alteración del orden público. Los menciono porque los he visto citados en varios artículos doctrinales ${ }^{101}$ y de prensa. Pero voy a intentar mantener la coherencia: Si en este trabajo he mantenido que, con similar eficacia, las medidas enumeradas permiten obviar el trámite del art. 155, no tendría sentido que invocase la utilidad de unas aún más contundentes medidas militares.

101 José A. Fernández Rodera: «A vueltas con el artículo 155 de la Constitución. Su relación con los estados excepcionales» en Actualidad Jurídica Aranzadi n. ${ }^{\circ}$ 603, pp. 1 a 5. 
Title:

Section 155 of the Spanish Constitution: doctrinal and comparative examination

\section{Summary:}

1. Introduction: A highly political, ambiguous and vague rule; 2 . Section 155 and regional tenseness. Examples of Comparative Law; 3. The unavoidable reference to the federal coercion in Germany. Section 155 and its comparison with section 37 of the Fundamental Law of Bonn; 4. The STGC of 5th of March, 1936; 5. The state coercion of section 155; 6. The former formal procedures to the state coercion of section $155 ; 7$. The supposed facts in which section 155 is applicable; 8 . The procedure of the state coercion; 9. The measures covered by section 155; 10 . The exceptional political and legal application of section 155; 11. The injuction of the Spanish Government and the Order of the Spanish Senate of 27th of October, 2017; 12. The application of the state coercion of section 155 in Catalonia; 13. The procedural question of the judicial review of the Order of the Senate; 14 . The motion filed by the political party UNIDOS-PODEMOS claiming that the application of section 155 is against the Spanish Constitution; 15. The Opinion 14/2017 of the Catalan Consell de Garanties Estatutarias. The motion filed by the Catalan Parliament for judicial review against the Order of the Spanish Senate; 16. The material question: Does the bloque de constitucionalidad entails a limit before section 155 ?

\section{Resumen:}

El art. 155 de la Constitución regula la coerción federal (federal coercion) con un texto inspirado en el art. 37 de la Ley Fundamental de Bonn, si bien presenta alguna importante diferencia, particularmente por la distinta configuración electoral del Senado y el Bundesrat. Su redacción es un ejemplo característico de la ambigüedad propia de los preceptos constitucionales; y su interpretación padece de que carece de desarrollo legislativo y precedentes históricos. Con su Resolución de 27 de octubre de 2017, el Senado ha aplicado por vez primera el art. 155 por entender que la Generalitat había incurrido en desobediencia a la Constitución. La autorización al Gobierno central conllevó el cese del Gobierno de Cataluña y la posterior disolución del Parlamento autonómico. Dos han sido los recursos de inconstitucionalidad instados, respectivamente, por el grupo parlamentario de Unidos-Podemos y por la Diputación Permanente del Parlamento de Cataluña. En este trabajo se aborda su análisis jurídico y se arriesga el vaticinio de Sentencia que habrá de dictar el Tribunal Constitucional. 


\begin{abstract}
:
Section 155 of the Spanish Constitution regulates federal coercion by means of a text inspired in section 37 of the Fundamental Law of Bonn, although the former presents some important differences, especially due to the different electoral configuration of the Spanish Senate and the Bundesrat. The wording of section 155 is a good example of the characteristic ambiguity of constitutional texts. Its interpretation suffers from a lack of legislative development and former precedents. By means of the Order of 27 th of October, 2017, the Spanish Senate has applied for the first time section 155, understanding that the Catalan Generalitat had violated the Constitution. The authorization given to the Spanish Government entailed the dismissal of the Autonomous Government of Catalonia and the dissolution of the Autonomous Parliament. Two motions have been filed, one by the parliamentary group Unidos-Podemos, and another by the $D i$ putación Permanente of the Parliament of Catalonia. This paper tackles the legal analysis of section 155, and risks predicting the future ruling of the Spanish Constitutional Court.
\end{abstract}

Palabras clave:

Coerción estatal; ambigüedad constitucional; desobediencia; instituciones autonómicas; potestades discrecionales del Gobierno.

Key words:

Federal coerción; constitutional ambiguity; disobedience; autonomous institutions; discretionary government powers. 